\title{
Characterization of submicron aerosols during a month of serious pollution in Beijing, 2013
}

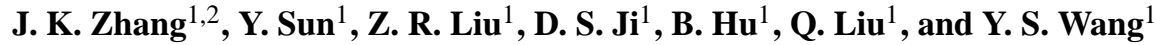 \\ ${ }^{1}$ State Key Laboratory of Atmospheric Boundary Layer Physics and Atmospheric Chemistry (LAPC), Institute of \\ Atmospheric Physics, Chinese Academy of Sciences, Beijing 100029, China \\ ${ }^{2}$ University of Chinese Academy of Sciences, Beijing 100049, China
}

Correspondence to: Y. S. Wang (wys@dq.cern.ac.cn)

Received: 23 May 2013 - Published in Atmos. Chem. Phys. Discuss.: 16 July 2013

Revised: 24 January 2014 - Accepted: 7 February 2014 - Published: 20 March 2014

\begin{abstract}
In January 2013, Beijing experienced several serious haze events. To achieve a better understanding of the characteristics, sources and processes of aerosols during this month, an Aerodyne high-resolution time-of-flight aerosol mass spectrometer (HR-ToF-AMS) was deployed at an urban site between 1 January and 1 February 2013 to obtain the size-resolved chemical composition of non-refractory submicron particles (NR-PM ${ }_{1}$ ). During this period, the mean measured NR-PM 1 mass concentration was $89.3 \pm 85.6 \mu \mathrm{g} \mathrm{m}^{-3}$, and it peaked at $423 \mu \mathrm{g} \mathrm{m}^{-3}$. Positive matrix factorization (PMF) differentiated the organic aerosol into five components, including a highly oxidized, low-volatility oxygenated organic aerosol (LV-OOA), a less oxidized, semi-volatile oxygenated OA (SV-OOA), a coal combustion OA (CCOA), a cooking-related OA (COA), and a hydrocarbon-like OA (HOA), which on average accounted for $28 \%, 26 \%, 15 \%$, $20 \%$ and $11 \%$ of the total organic mass, respectively.

A detailed comparison between the polluted days and unpolluted days found many interesting results. First, the organic fraction was the most important NR-PM $\mathrm{PM}_{1}$ species during the unpolluted days $(58 \%)$, while inorganic species were dominant on polluted days (59\%). The OA composition also experienced a significant change; it was dominated by primary OA (POA), including COA, HOA and CCOA, on unpolluted days. The contribution of secondary OA (SOA) increased from $35 \%$ to $63 \%$ between unpolluted and polluted days. Second, meteorological effects played an important role in the heavy pollution in this month and differed significantly between the two types of days. The temperature and relative humidity $(\mathrm{RH})$ were all increased on polluted days and the wind speed and air pressure were decreased. Third,
\end{abstract}

the diurnal variation trend in NR-PM $\mathrm{PM}_{1}$ species and OA components showed some differences between the two types of days, and the OA was more highly oxidized on polluted days. Fourth, the effects of air masses were significantly different between the two types of days; air was mainly transported from contaminated areas on the polluted days. The comparison also found that the aerosol was more acidic on polluted days. Additionally, the variation trends of the mass concentration and mass fractions of NR-PM $\mathrm{PM}_{1}$ species and OA components were more dramatic when the NR-PM $\mathrm{P}_{1}$ mass loading was at a higher level. The serious pollution observed in this month can be attributed to the synergy of unfavorable meteorological factors, the transport of air masses from highpollution areas, emission by local sources, and other factors.

\section{Introduction}

Beijing is one of the most economically developed regions in China, with a population of more than 20 million and a vehicle fleet of approximately 5 million (Beijing Municipal Bureau of Statistics). The rapid development of a variety of industries, including power generation, industrial production, and transportation, have resulted increased emission of particulate matter (PM). The most serious PM pollution of this century appeared in January 2013, when the highest instantaneous concentration of $\mathrm{PM}_{2.5}$ reached $1000 \mu \mathrm{g} \mathrm{m}^{-3}$ in some heavily polluted areas of Beijing. Up to 0.8 billion people in China were affected. The submicron particle concentration also reached a high level during this month. Unlike coarse particles, fine particles can penetrate deeply into the 
lung, leading to adverse effects on human health. These particles also have important effects on visibility, climate forcing, and the deposition of acids and nutrients to ecosystems and crops (Ulbrich et al., 2009). However, the submicron particles affecting China are still poorly understood because their heterogeneous distribution and short atmospheric lifetimes make it difficult to characterize their chemical and physical properties (Mohr et al., 2011).

In addition to inherent difficulties posed by the nature of fine particles, our level of understanding of the nature, sources, processes and effects of fine particles is currently limited by the available instrumentation. Most previous aerosol studies have been based on filter samplings followed by laboratory analyses. However, this analysis method has many drawbacks: its resolution is lower, the experiments are limited by the small amount of material collected, and organic aerosols cannot be analysis in-depth. (Hildebrandt et al., 2010; Huang et al., 2010; Ge et al., 2012a). Aerosol mass spectrometers (AMS) have been widely applied in recent years because they allow for chemical speciation and for the sizing and mass detection of submicron non-refractory $\mathrm{PM}_{1}$ at a high time resolution (Canagaratna et al., 2007; Mohr et al., 2012). The application of high-resolution time-of-flight aerosol mass spectrometer (HR-ToF-AMS) for ambient studies is relatively new; it has been used only in recent years (DeCarlo et al., 2006). The use of HR-ToF-AMS provides significantly improved chemical resolution and sensitivity. In particular, the high $m / z$ resolution of the HR-ToF-AMS allows for most ion fragments to be resolved and for their nominal elemental compositions to be determined (Aiken et al., 2008; Sun et al., 2011b).

Over the last decade, many aerosol studies have revealed that organic aerosol (OA) is the most abundant component of fine particles and that it makes up a large fraction (20 to $90 \%$ ) of the submicron particulate mass (Murphy et al., 2006; Zhang et al., 2007). OA is the sum of multiple primary and secondary sources that can evolve due to aging processes. Correctly apportioning organic aerosols into their sources and components is a critical step towards enabling efficient control strategies and model representations (Ulbrich et al., 2009). Recently, AMS data have been combined with positive matrix factorization (PMF) to study OA in depth, which has led to new insights into the sources contributing to OA (Lanz et al., 2007; Ulbrich et al., 2009; Mohr et al., 2012). Based on the AMS measurements, hydrocarbon-like OA (HOA) from traffic, biomass burning OA (BBOA), and oxygenated $\mathrm{OA}(\mathrm{OOA})$ have been distinguished in many data sets where secondary organic aerosol (SOA) is assumed to be the main contributor to OOA (Jimenez et al., 2009; Lanz et al., 2010). In addition, some studies further separated the OOA into a low volatility fraction (LV-OOA) and a semivolatile fraction (SV-OOA) (Lanz et al., 2007; Aiken et al., 2008; Huang et al., 2010, 2011; Mohr et al., 2012).

Although it is the capital of China and experiences some of the worst air pollution in the world, there are currently only a handful of reports focused on AMS studies of submicron particles in Beijing. In 2006, Sun et al. (2010) first used a Q-AMS to study non-refractory submicron particles $\left(\mathrm{NR}-\mathrm{PM}_{1}\right)$ in Beijing in the summer. They found that the mean mass concentration was approximately $80 \mu \mathrm{g} \mathrm{m}^{-3}$ and three OA components were first determined based on AMS organic spectra. In 2008, the first study to use a HR-ToFAMS found that there was a significant decrease in NR-PM 1 since the previous study; the mean mass concentration was found to be $61.1 \mu \mathrm{g} \mathrm{m}^{-3}$, and OA was differentiated into four components: hydrocarbon-like OA (HOA), cooking-related OA (COA), and two oxygenated OA (OOA-1 and OOA-2). Sun et al. $(2012,2013 b)$ used an Aerodyne aerosol chemical speciation monitor (ACSM) to study NR-PM $\mathrm{PM}_{1}$ in summer and winter in Beijing; they found that the composition of NR-PM 1 , the diurnal behaviors of NR-PM 1 species, and the sources of $\mathrm{OA}$ were quite different between summer and winter. However, the ACSM could not provide information on the particle size distribution, and its resolution is lower than that of the HR-ToF-AMS. The only study based on HR-ToFAMS conducted in winter in Beijing focused exclusively on OA. Meanwhile, the AMS was only operated under V mode, another useful mode, $\mathrm{W}$ mode, was not utilized (Liu et al., 2012). Therefore, further HR-ToF-AMS studies of submicron particles in winter in Beijing are needed.

For this study, we deployed a high-resolution time-offlight aerosol mass spectrometer (for the sake of simplicity, we will refer to this instrument as AMS in the following discussion), manufactured by Aerodyne Research Inc. (Billerica, MA, USA), in urban Beijing to measure airborne submicron particles with a high time resolution during a month of serious pollution. The main findings include (1) the mass concentrations, size distributions, chemical composition, and temporal and diurnal variations of NR-PM 1 species; (2) the characteristics and dynamic variations of the OA components as determined via positive matrix factorization (PMF) of the high-resolution mass spectra (HRMS); and (3) an analysis and comparison of the characteristics, sources and impact factors of NR-PM 1 and OA components during unpolluted and polluted days.

\section{Experimental methods}

\subsection{Sampling site description}

Online AMS measurements of the chemical composition and size distribution of the NR-PM 1 aerosol components were performed continuously between 1 January and 1 February 2013, at the Institute of Atmospheric Physics (IAP), Chinese Academy of Sciences (CAS) (Fig. S1). The observation site is located between the north 3rd Ring Road and north 4th Ring Road. The site is approximately $1 \mathrm{~km}$ from the 3rd Ring Road, $200 \mathrm{~m}$ from the Badaling Highway running north-south to its east, and $50 \mathrm{~m}$ from the Beitucheng 
West Road running east-west to its north. Ambient air was sampled at approximately $15 \mathrm{~m}$ above the ground.

Simultaneously, an automatic meteorological observation instrument (Milos520, Vaisala, Finland) was located at the $8 \mathrm{~m}$ level and was used to observe key meteorological parameters, including temperature, humidity, air pressure, and the speed and direction of wind in the atmosphere at ground level. Data on $\mathrm{NO}_{\mathrm{x}}$ were acquired from the Beijing-TianjinHebei Atmospheric Environment Monitoring Network (a long-term observation network). These data were measured using an $\mathrm{NO}-\mathrm{NO}_{2}-\mathrm{NO}_{\mathrm{x}}$ chemiluminescence analyzer (Model 42i, Thermo-Fisher Scientific (TE), USA). Data were collected every $5 \mathrm{~min}$. Ambient air was sampled at approximately $8 \mathrm{~m}$ above ground. The distance between the sample inlets of HR-ToF-AMS and the $\mathrm{NO}_{\mathrm{x}}$ detection instrument was approximately $20 \mathrm{~m}$.

\subsection{HR-ToF-AMS measurement and data processing}

\subsubsection{HR-ToF-AMS operation}

A detailed description of the instrument can be found in DeCarlo et al. (2006). During this campaign, the AMS was operated under both the "V" and "W" ion optical modes, alternating every $7.5 \mathrm{~min}$. The $\mathrm{V}$-mode is more sensitive, whereas the $\mathrm{W}$-mode has a higher mass resolution. Under V-mode operation, the AMS cycled through the mass spectrum (MS) mode and the particle time-of-flight (PToF) mode every $45 \mathrm{~s}$, spending $22.5 \mathrm{~s}$ and $22.5 \mathrm{~s}$ in its open and closed status under the MS mode, respectively. No PToF data were sampled in $\mathrm{W}$-mode due to its limited signal-to-noise $(\mathrm{S} / \mathrm{N})$ ratio. However, the high mass resolution $(\sim 5000-6000)$ of W-mode allowed for the determination of the ion-specific mass spectra and thus the elemental compositions of OA (DeCarlo et al., 2006; Aiken et al., 2008).

The AMS was calibrated for inlet flow, ionization efficiency (IE), and particle sizing at the beginning, middle and end of the campaign following standard protocols (Jayne et al., 2000; Jimenez, et al., 2003; Drewnick et al., 2005). IE calibration was conducted using size-selected pure ammonium nitrate particles, and particle size calibration was conducted using mono-disperse polystyrene latex spheres. The detection limit (DL) of each individual species was taken to be three times the standard deviation of the corresponding signal in particle-free air (DeCarlo et al., 2006; Sun et al., 2009). As a result, the 5 min DLs of organics, sulfate, nitrate, ammonium, and chloride were 0.056, 0.006, 0.008, 0.04 and $0.014 \mu \mathrm{g} \mathrm{m}^{-3}$, respectively.

\subsubsection{HR-ToF-AMS data analysis}

The mass concentrations and size distributions of the species measured with the AMS were calculated using methods outlined in DeCarlo et al. (2006). The standard ToFAMS data analysis software packages SQUIRREL version
1.50 and PIKA version 1.09, both downloaded from the ToF-AMS-Resources web page (http://cires.colorado.edu/ jimenez-group/ToFAMSResources), were used to generate unit and high-resolution mass spectra from the V-mode and W-mode data, respectively (Huang et al., 2010; He et al., 2011). The V-mode and PToF data were processed using SQUIRREL to determine the mass concentrations and size distributions of the NR-PM 1 species, and the W-mode data were processed using PIKA to obtain high-resolution mass spectra and identify the elemental compositions of the organic species.

A collection efficiency (CE) was introduced to account for the incomplete transmission and detection of particles by the HR-ToF-AMS during this study. Middlebrook et al. (2012) evaluated the dependency of CE on aerosol composition and concluded that the $\mathrm{CE}$ of acidic particles or particles with a high nitrate fraction (e.g., $\mathrm{NH}_{4} \mathrm{NO}_{3} 40 \%$ of $\mathrm{PM}_{1}$ ) may increase, whereas the CE of dry particles does not show significant change with the organic fractions. In this study, to reduce the uncertainty in CE due to particle-phase water, a silica gel diffusion dryer was introduced to keep the relative humidity in the sampling line below $40 \%$. In addition, as presented in Fig. S2, the mass fraction of ammonium nitrate (ANMF) in this study was normally below 0.4. Ammonium nitrate is thus expected to have only a minor effect on CE. Therefore, the CE is mainly driven by aerosol acidity, and the relationship between $\mathrm{CE}$ and aerosol acidity can be parameterized as $\mathrm{CE}_{\text {dry }}=\max \left(0.45,1.0-0.73\left(\mathrm{NH}_{4} / \mathrm{NH}_{4}\right.\right.$,predict $\left.)\right)$ (Middlebrook et al., 2012). Because high-acidity aerosol was observed in this study (Sect. 3.5.3), variable CEs that were calculated using the equation above were applied. The relative ionization efficiency (RIE) values used in this study were 4.0 for ammonium, 1.2 for sulfate, 1.1 for nitrate, 1.3 for chloride and 1.4 for organics (Jimenez et al., 2003).

Positive matrix factorization (PMF) (Paatero and Tapper, 1994) analyses were performed on the HRMS (i.e., the ion-speciated W-mode spectra) using the PMF Evaluation Toolkit (PET) v2.05 (Ulbrich et al., 2009). The HRMS data and error matrices were generated as outlined in DeCarlo et al. (2010). Data and error matrices were first generated in PIKA. We considered only ions up to $m / z 120$, given that larger ions had a low signal-to-noise ratio and were more biased because of an insufficient mass resolution. Isotopes were systematically constrained in PIKA, but they were then removed from the data and error matrices because their presence would have given excess weight to the parent ions in the PMF analysis (Setyan et al., 2012). Ions with an S/N ratio $<0.2$ were removed from the HRMS data and error matrices before the PMF analysis. The "weak" ions with S/N between 0.2 and 2 were downweighted by increasing their errors by a factor of 2 (Paatero and Hopke, 2003; Ulbrich et al., 2009). More technical details on the PMF analysis can be found in other recent publications (Ulbrich et al., 2009).

The PMF analysis based on the HRMS data set observed in the campaign was performed for 1 to 8 factors. 
Detailed information can be found in the supplementary information (discussion S1 and Fig. S3). Finally, the 5-factor, FPEAK $=-0.1$, seed $=0$ solution was chosen as the optimal solution for this analysis.

An elemental analysis of the HRMS data for $\mathrm{C}, \mathrm{H}, \mathrm{O}$, and $\mathrm{N}$ time series and ratios was performed using the APES v1.05 software within Igor Pro 6.21A.

\section{Results and discussion}

\subsection{Submicron aerosol characteristics}

Figure 1 presents the time-resolved variation of organic, nitrate, sulfate, ammonium, and chloride mass concentrations measured with the AMS and of the meteorological parameters (e.g., temperature, $\mathrm{RH}$, wind speed and direction) from 1 January to 1 February 2013.

The meteorological conditions during the campaign are presented in Fig. 1a and b. The temperature had clear diurnal cycles, with higher values observed during the daytime. Relative humidity showed peak values during the night. During the campaign, the temperature varied from $-12.1^{\circ} \mathrm{C}$ to $4.6^{\circ} \mathrm{C}$, with an average of $-2.8 \pm 3.1^{\circ} \mathrm{C}$. Relative humidity was in the range of $11 \%$ to $92 \%$, averaging $49 \pm 23 \%$. Wind speed varied from $0 \mathrm{~m} \mathrm{~s}^{-1}$ to $8.1 \mathrm{~m} \mathrm{~s}^{-1}$, with an average of $1.5 \pm 1.1 \mathrm{~m} \mathrm{~s}^{-1}$ during the sampling period.

Figure $1 \mathrm{c}$ and $\mathrm{d}$ present the time series for the NR-PM species mass concentration and NR-PM 1 components during the campaign, respectively. Several serious pollution events occurred during the month of the campaign. Therefore, the range of NR-PM $M_{1}$ mass concentrations was broad; values ranging from 3.3 to $423 \mu \mathrm{g} \mathrm{m}^{-3}$ were observed, and the mean mass concentration was $89.3 \pm 85.6 \mu \mathrm{g} \mathrm{m}^{-3}$. These values are much higher than those observed in developed countries, such as the concentration of $11.0 \mu \mathrm{g} \mathrm{m}^{-3}$ observed in New York City in 2009 (Sun et al., 2011b) and the concentration of $14.8 \mu \mathrm{g} \mathrm{m}^{-3}$ observed in Pittsburgh in 2002 (Zhang et al., 2005a). In addition, these values are higher than the other results measured in Beijing in $2006\left(80.0 \mu \mathrm{g} \mathrm{m}^{-3}\right)$ by Sun et al. (2010) and in $2008\left(61.1 \mu \mathrm{g} \mathrm{m}^{-3}\right)$ by Huang et al. (2010). Similar to the total mass, the mass concentration of all the individual species also varied significantly. Organics, for example, sometimes reached concentrations over $180 \mu \mathrm{g} \mathrm{m}^{-3}$ and sometimes dropped to less than $2 \mu \mathrm{g} \mathrm{m}^{-3}$.

Figure $\mathrm{S} 4$ shows the time series for the NR-PM $\mathrm{PM}_{1}$ concentrations measured using AMS and a tapered element oscillating microbalance (TEOM, Rupprecht \& Patashnick Co., Inc, model 1400A, Albany, New York) that was equipped with a Nafion diffusion dryer sample equilibration system (SES) along with a $\mathrm{PM}_{2.5}$ inlet and sampled at $50^{\circ} \mathrm{C}$. The two measurements are highly correlated, with a linear correlation coefficient $\left(R^{2}\right)$ of 0.88 and a slope of 0.68 (Fig. S5).

As shown in Fig. 1e, organics were the most abundant NR-PM 1 species on average, accounting for $50 \%$ of the to-
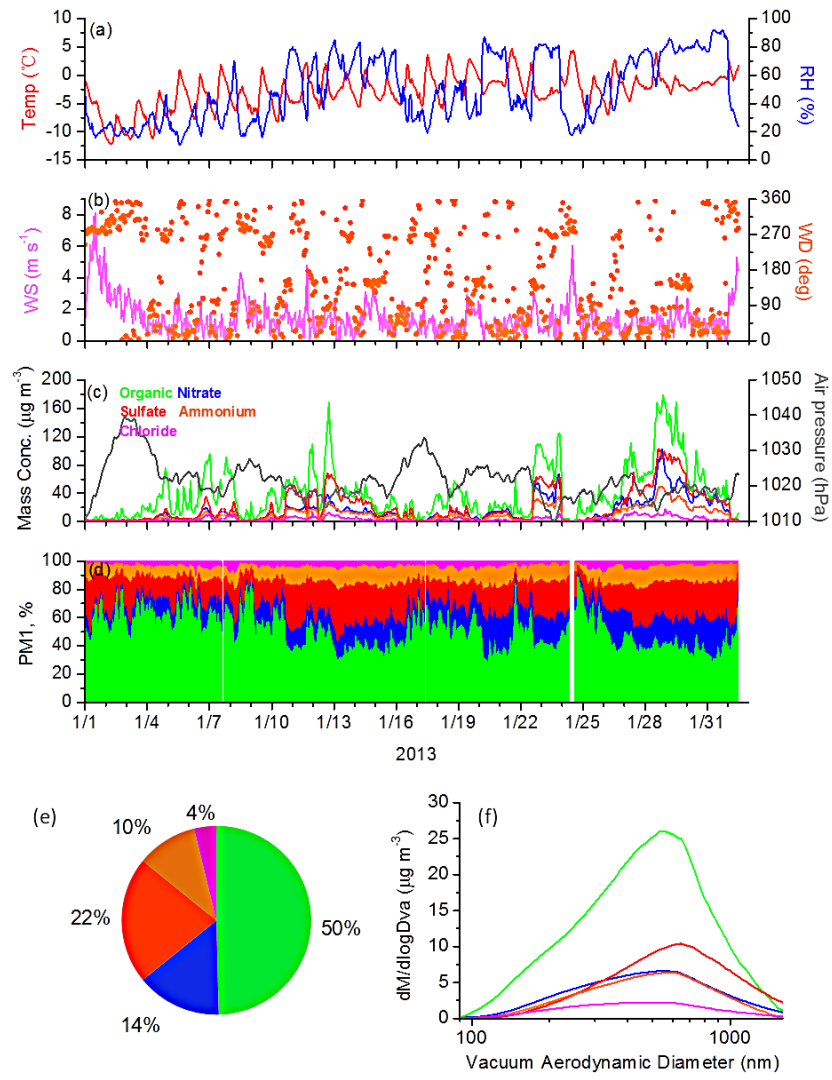

Fig. 1. Chemical compositions and size distributions of the NR$\mathrm{PM}_{1}$ during the campaign: time series of (a) ambient temperature and relative humidity; (b) wind direction and wind speed; (c) NR$\mathrm{PM}_{1}$ species concentrations and air pressure; (d) NR-PM 1 percent composition; (e) NR-PM 1 chemical composition; and (f) the average size distributions of the AMS species.

tal mass, followed by sulfate ( $22 \%)$, nitrate $(14 \%)$, ammonium $(10 \%)$, and chloride (4\%). The contribution of organics detected here is much higher than that observed in previous studies in summer in Beijing in 2006 (35\%) (Sun et al., 2010) and 2008 (39\%) (Huang et al., 2010), but it is consistent with the previously reported results for winter in 2012 (52\%) (Sun et al., 2013b). In addition, our value is consistent with measures of the contribution of organics observed in some foreign cities, such as New York City (54\%) (Sun et al., 2011b) and Whistler Mountain (55\%) (Sun et al., 2009). We must note that black carbon (BC) was included in the studies of Beijing in 2008 and of New York City in 2009. Therefore, we excluded the BC and recalculated the contribution of every species (organics, sulfate, nitrate, ammonium and chloride) based on the data provide in these studies. Although we found the contribution of chloride to be lower than that of the other species, consistent with observations in summer, we found its contribution to be much higher than that reported in summer in $2011(1 \%)$, likely due to the intensified 
emissions from coal combustion during the heating season (Sun et al., 2012).

Figure if presents the average mass-size distributions of each species determined by the AMS during the campaign. Generally, all species showed an apparent accumulation mode peaking at a relatively large size $(600 \mathrm{~nm})$, which is indicative of an aged regional aerosol (Zhang et al., 2005b). In addition, organics and nitrate showed an additional mass distribution at smaller sizes $(200 \mathrm{~nm})$. The small size mode of the organics is most likely associated with primary emissions from vehicles, coal burning or other primary sources (Canagaratna et al., 2004; Huang et al., 2010). Xiao et al. (2009) suggested that combustion-related emissions (e.g., traffic emissions) are likely the main source of the smaller mode. An enrichment of organics at smaller sizes was also observed in other urban AMS measurements (Aiken et al., 2009; Huang et al., 2010). The smaller mode of nitrate may suggest that nitrate's formation pathways are more complex than are those of other inorganic species. Atmospheric nitrate formation pathways mainly include the heterogeneous hydrolysis of $\mathrm{N}_{2} \mathrm{O}_{5}$ during the night and the gasphase photochemical production of $\mathrm{HNO}_{3}$ during the daytime. The ambient nitrate concentration is also driven by the gas-to-particle partitioning of ammonium nitrate and boundary layer dynamics (Sun et al., 2013a). The broader size distribution of nitrate was also observed in 2006 in Canada (Sun et al., 2009). The complex formation pathways of nitrate have been discussed in many studies (Sun et al., 2011a).

\subsection{Elemental composition of organic aerosol}

The HRMS obtained in this study enabled the investigation of the molecular ratios of $\mathrm{C}, \mathrm{H}, \mathrm{O}$ and $\mathrm{N}$ in the organic aerosol. Figure $2 \mathrm{a}$ and $\mathrm{b}$ show the variations in the atomic ratios of $\mathrm{H} / \mathrm{C}, \mathrm{N} / \mathrm{C}$ and $\mathrm{O} / \mathrm{C}$ and the mass ratios of the $\mathrm{OM} / \mathrm{OC}$ of OA during this campaign. The $\mathrm{H} / \mathrm{C}$ ratio varied within a range of $1.33-1.68$, with a mean value of $1.44 \pm 0.05$, whereas the $\mathrm{O} / \mathrm{C}$ ratio varied within a range of $0.14-0.58$, with a mean value of $0.34 \pm 0.08$. The $\mathrm{O} / \mathrm{C}$ atomic ratio has been considered a good reference for the oxidation state and photochemical age of OA (Jimenez et al., 2009; $\mathrm{Ng}$ et al., 2010). This value is lower than that observed at Kaiping (0.47), a rural site downwind of the central Pearl River Delta area that receives pollutants through regional transport (Huang et al., 2011). This difference indicates that the pollutants emitted in an urban area age during the transport process, and the value reported here is fairly similar to other observed in Beijing (0.33) (Huang et al., 2010), Shenzhen (0.30) (He et al., 2011), Mexico City (0.38) (Aiken et al., 2009) and New York City (0.36) (Sun et al., $2011 \mathrm{~b}$ ). The $\mathrm{N} / \mathrm{C}$ ratio varied between 0.005 and 0.026 , with a mean value of $0.015 \pm 0.004$.

The OM/OC ratio varied between 1.33 and 1.92 during this campaign, with an average of $1.60 \pm 0.11$. The OM/OC mass ratio has been used extensively to convert the organic carbon mass to the organic matter mass in filter-based aerosol chemistry studies. The OM/OC ratio correlated well with the $\mathrm{O} / \mathrm{C}$ ratio $\left(R^{2}=0.99\right.$, Fig. S6). The mean OM/OC value in Beijing measured in this study is consistent with the previously reported value of $1.60( \pm 0.2)$ for an urban aerosol (Turpin and Lim, 2001), and the results are similar to those measured in Shenzhen (1.57) (He et al., 2011) and New York City (1.62) (Sun et al., 2011b).

Figure $2 \mathrm{c}$ and $\mathrm{d}$ present the average diurnal variations of the $\mathrm{H} / \mathrm{C}, \mathrm{N} / \mathrm{C}, \mathrm{O} / \mathrm{C}$ and $\mathrm{OM} / \mathrm{OC}$ ratios. Because these ratios are influenced by relative organic constitutions rather than absolute organic concentrations, their diurnal patterns can be predominantly attributed to the diurnal variations in the relative importance of different sources (Huang et al., 2011). Both the $\mathrm{O} / \mathrm{C}$ and $\mathrm{OM} / \mathrm{OC}$ ratios reached peaks at 15:00-16:00 LT (note that all times throughout the text are in local time), which is when the photochemical production of secondary organic aerosols (SOA) with high $\mathrm{O} / \mathrm{C}$ ratios is greatest. Similar results were obtained from the Pearl River Delta of China (He et al., 2011) and New York City (Sun et al., 2011b). However, this study detected an additional, significantly reduced at 12:00 that was not reported in other studies. This phenomenon may have been caused by the relative contribution of the cooking source, which is a primary source of organic aerosol with a lower $\mathrm{O} / \mathrm{C}$ ratio and is more prevalent in Beijing. The $\mathrm{H} / \mathrm{C}$ ratio showed a diurnal pattern opposite to those observed for $\mathrm{O} / \mathrm{C}$ and $\mathrm{OM} / \mathrm{OC}$, as expected. However, the N/C diurnal pattern was generally consistent with the pattern observed for $\mathrm{O} / \mathrm{C}$ and $\mathrm{OM} / \mathrm{OC}$.

Figure 2e shows a Van Krevelen diagram (H/C vs. O/C) of OA using the data observed in Beijing. A significant anticorrelation $\left(R^{2}=0.43\right)$ with a slope of -0.43 was obtained. This slope is shallower than that observed in Shenzhen (approximately -0.74 ) (He et al., 2011). As suggested by Heald et al. (2010), the shallower OA slope in the Van Krevelen diagram might reflect different aging mechanisms and/or the relative mixing of fresh and aged air masses in Beijing (Heald et al., 2010). On average, $\mathrm{C}, \mathrm{H}, \mathrm{O}$, and $\mathrm{N}$ contributed $73.6 \%$, $7.2 \%, 16.5 \%$ and $2.8 \%$, respectively, to the total organic mass (Fig. 2f).

\subsection{Investigating $\mathrm{OA}$ components/sources with positive matrix factorization (PMF)}

The five organic components identified in this campaign included a highly oxidized and low-volatility OOA (LV-OOA), a less oxidized and semi-volatile OOA (SV-OOA), a coal combustion OA (CCOA), a cooking-related OA (COA), and a hydrocarbon-like OA (HOA). Figure 3 shows the MS profiles for the five components, and Fig. 4 shows the time series for the OA components and other relevant species. PMF components were identified by their MS signatures and the correlation of their time series with tracers and were then confirmed using additional information, such as diurnal cycles (Zhang et al., 2005b; Ulbrich et al., 2009). 

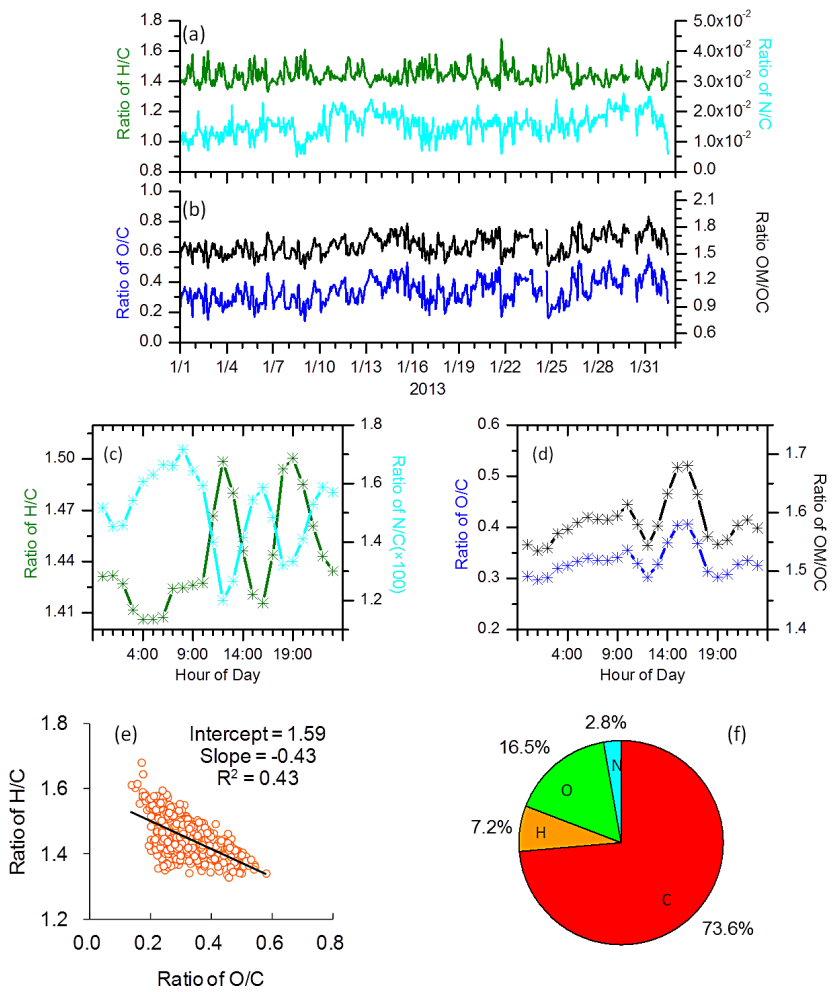

Fig. 2. The time series of (a) $\mathrm{H} / \mathrm{C}$ and $\mathrm{N} / \mathrm{C}$ ratios and (b) $\mathrm{O} / \mathrm{C}$ and $\mathrm{OM} / \mathrm{OC}$ ratios; and the average diurnal variations of (c) $\mathrm{H} / \mathrm{C}$ and $\mathrm{N} / \mathrm{C}$ ratios and (d) O/C and OM/OC ratios; (e) The Van Krevelen diagram; and (f) the average mass-based organic elemental composition.

OOAs have been extensively identified in previous AMS studies (Sun et al., 2011b; Huang et al., 2011) and are generally dominated by secondary organic aerosols that are formed in the atmosphere through the gas-to-particle conversion of the oxidation products of volatile organic compounds (Hallquist et al., 2009). The MS of LV-OOA and SV-OOA were similar; they had $\mathrm{O} / \mathrm{C}$ ratios of 0.84 and 0.40 , respectively. Both were characterized by prominent $\mathrm{C}_{x} \mathrm{H}_{y} \mathrm{O}_{z}$ fragments, especially $\mathrm{CO}_{2}^{+}(m / z 44)$, suggesting the prevalence of oxidized organic compounds. The MS of SV-OOA also displayed a significant signal at the ion series $\mathrm{C}_{n} \mathrm{H}_{2 n+1}^{+}(\mathrm{m} / z$ $29,43,57)$ and $\mathrm{C}_{n} \mathrm{H}_{2 n-1}^{+}(m / z, 41,55)$ from saturated alkanes, alkenes, and cycloalkanes that was low in the MS of LV-OOA.

The $\mathrm{O} / \mathrm{C}$ ratio of the LV-OOA identified in this campaign (0.84) was higher than the $\mathrm{O} / \mathrm{C}$ ratio reported in studies in other locations, including Kaiping (0.64) (Huang et al., 2011), Shenzhen (0.59) (He et al., 2011) and New York City (0.63) (Sun et al., 2011b), whereas the O/C ratio of SV-OOA (0.40) was close to that reported in those studies $(0.39,0.45$ and 0.38 , respectively). The LV-OOA time series showed a similar trend to the sulfate time series $\left(R^{2}=0.84\right)$ (Fig. 4), consistent with the relationship between LV-OOA

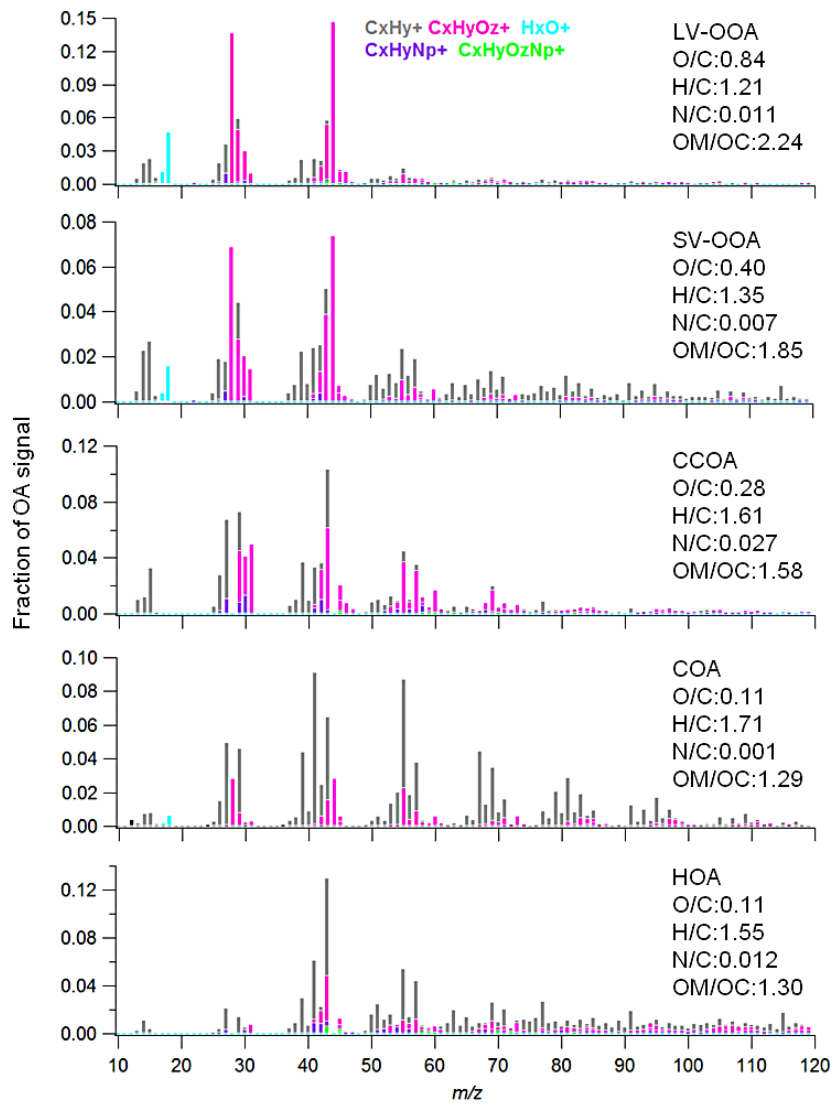

Fig. 3. The AMS $m / z$ profiles of the five OA components identified by PMF in this study.

and sulfate observed in other studies, for example, He et al. (2011) and DeCarlo et al. (2010). However, the correlation coefficient $\left(R^{2}\right)$ between SV-OOA and nitrate found in this study was 0.25 , which is not as high as the values found in other studies, such as 0.65 and 0.66 for the Pearl River Delta region in South China (Huang et al., 2011; He et al., 2011). However, this value is higher than the results found in Barcelona $\left(R^{2}=0.22\right)$ (Mohr et al., 2012) and New York City $\left(R^{2}=0.05\right)$ (Sun et al., 2011b). The lower correlation can be explained by the more complex generation mechanisms of the two components in winter, especially the effect of aqueous-phase processing due to the fog process, as discussed in Sect. 3.5. The two studies in the Pearl River Delta were conducted in summer.

The pie chart in Fig. 4 indicates that the OA mass can be explained by the PMF factors. LV-OOA and SV-OOA make up $28 \%$ and $26 \%$ of the OA, respectively, which is very close to the previous findings obtained in Barcelona, where the contributions of LV-OOA and SV-OOA to OA were $28 \%$ and $27 \%$, respectively (Mohr et al., 2012). The contribution of OOA (LV-OOA+SV-OOA, $54 \%$ ) measured here was slightly lower than some results measured in summer in Beijing, such as $57.4 \%$ in 2008 and $61 \%$ in 2006 (Huang et al., 2010; Sun et al., 2010). Our measurement was conducted in 


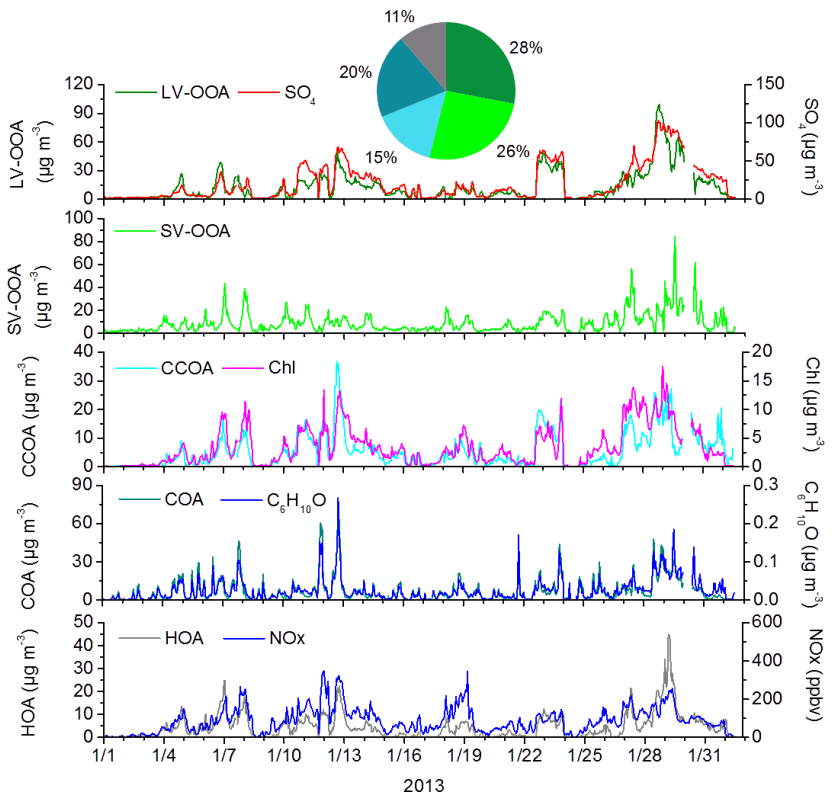

Fig. 4. The average OA composition and time series of the OA components and other relevant species.

winter, when the temperature and oxidation state of the atmosphere are lower than in summer.

Although coal has gradually been replaced with other fuels, such as oil, natural gas and clean energy, in some countries with higher economic development levels, coal remains the most important fuel in China due to an underdeveloped energy structure. Coal has been widely used in various industries in China, including power generation, steel milling, and cement production. Moreover, coal is the primary fuel used for winter heating in northern China. In recent years, there have been more concerns about OA emissions from coal combustion due to their important impacts on climate changes and health effects (Zhang et al., 2008; Sun et al., 2013b). Zhang et al. (2012) found that coal combustion in China emits a large quantity of carbonaceous aerosols, contributing approximately $70 \%$ of the total emitted $\mathrm{PM}_{2.5}$ (Zhang et al., 2012). As in Sun et al. (2013b) and Hu et al. (2013), CCOA was identified in this campaign. Overall, the MS for CCOA observed in this study is similar to those observed in their studies. Additionally CCOA's MS in our study is also close to the BBOA MS in other studies, with a prominent contribution of $m / z 60$, which is a good tracer ion for biomass burning-emitted aerosols (Alfarra et al., 2007; Aiken et al., 2009). However, the contribution of $m / z 73 \mathrm{ob}$ served in our study is less than that in the MS of BBOA. Wang et al. (2013) found that the similarity between organic signals from coal combustion and biomass burning measured by both AMS and ATOFMS may render some "biomass burning aerosol tracers" unreliable. Considering the energy structure in Beijing and the prevalence of coal combustion in winter, we thought it more reasonable to identify this OA component as CCOA. The mass spectrum of CCOA is dominated by alkyl fragments $\left(\mathrm{C}_{n} \mathrm{H}_{2 n+1}^{+}\right.$and $\left.\mathrm{C}_{n} \mathrm{H}_{2 n-1}^{+}\right)$, which is typical of primary organic aerosols derived from fossil fuel combustion. The $\mathrm{H} / \mathrm{C}$ and $\mathrm{O} / \mathrm{C}$ ratios for CCOA were 1.61 and 0.28 , respectively, both of which are higher than the ratios for HOA (1.55 and 0.11). As the results measured in the winter in Beijing 2012, the CCOA showed a similar trend to the time series for chloride $\left(R^{2}=0.70\right)$ (Fig. 4). Although chloride has been used as a tracer for BBOA, Zhang et al. (2012) found that the contribution of chloride from coal combustion $(0.64 \%)$ was even higher than that from wood burning $(0.45 \%)$ (Zhang et al., 2012).

The average CCOA fraction of the total OA was approximately $15 \%$ (Fig. 4). This value is higher than the results measured by Hu et al. (2013) (9\%). This is because they excluded some OA data corresponding to the periods most strongly influenced by coal combustion, so the contribution of coal combustion to organic aerosol concentrations should be larger than the value they reported. Sun et al. (2013b) found that CCOA was the most important primary source during wintertime, on average accounting for $33 \%$ of OA and $17 \%$ of NR-PM ${ }_{1}$, which is almost equivalent to the sum of HOA and COA. CCOA accounts for a considerable fraction of OA and NR-PM 1 throughout the day, ranging from $26-37 \%$ and $12-22 \%$, respectively, indicating that coal has a sustained impact on PM pollution throughout the day (Sun et al., 2013b).

The COA MS extracted in this study had a low O/C ratio (0.11) and a unique diurnal pattern. The MS of the COA was characterized by $\mathrm{C}_{x} \mathrm{H}_{y}^{+}$, especially $\mathrm{C}_{n} \mathrm{H}_{2 n-1}^{+}$, including $\mathrm{m} / \mathrm{z} 41$ and $\mathrm{m} / \mathrm{z} 55$; the contributions of these two $\mathrm{m} / \mathrm{z}$ were $9.1 \%$ and $8.9 \%$, respectively (Fig. 3). This result indicates a significant presence of unsaturated organic compounds (e.g., unsaturated fatty acids) and is consistent with the MS characteristics measured for primary Chinese cooking emissions (He et al., 2010). In addition, COA showed significant correlations with a few $\mathrm{C}_{x} \mathrm{H}_{y} \mathrm{O}_{1}^{+}$ions, including $\mathrm{C}_{6} \mathrm{H}_{10} \mathrm{O}^{+}$(Fig. 4), which are prominent peaks in the sources spectra of cooking emissions; these ions could be used as spectral markers for COA (Sun et al., 2011b). Due to the uniqueness of Chinese cooking habits and culture, cooking emissions have been regarded as one of the major organic aerosol sources that in urban Chinese environments, and the cooking contribution to OA (20\%) is slightly higher than in some foreign cities such as in Barcelona (17.0\%) and New York City (16.0\%) (Sun et al., 2011b; Mohr et al., 2012). The contribution of COA reported in this study is close to that reported at a similar site in Beijing during the winter of 2012 (19\%) (Sun et al., 2013b).

HOA has been extensively identified in previous factor analyses of AMS ambient aerosol data sets (Huang et al., 2010; He et al., 2011; Mohr et al., 2012). This component can be distinguished by the ion series $\mathrm{C}_{n} \mathrm{H}_{2 n+1}^{+}$and $\mathrm{C}_{n} \mathrm{H}_{2 n-1}^{+}$ and by low $\mathrm{O} / \mathrm{C}$ ratios ( $<0.2)$ (Jimenez et al., 2009; $\mathrm{Ng}$ et al., 2010) (Fig. 3). The lower O/C ratio (0.11) and higher H/C 
(1.55) detected during this campaign are consistent with the previous results observed for Beijing (Huang et al., 2010) and Shanghai (Huang et al., 2012). In addition, HOA correlates well with combustion tracers such as $\mathrm{NO}_{\mathrm{x}}\left(R^{2}=0.61\right)$. This finding indicates that the HOA is likely a surrogate for combustion POA, as concluded in other studies (Aiken et al., 2009; Ulbrich et al., 2009). In other studies in Beijing, HOA always was the lowest OA component, and it accounted for $11 \%$ of the OA in our study. However, we should not ignore those POA components with lower contributions compared to SOA, because they are the important OA components during unpolluted days (Sect. 3.5).

\subsection{Back trajectory clustering analysis}

The hybrid single-particle Lagrangian integrated trajectory (HYSPLIT) model is a useful air trajectory model, especially for studying the long-range transport of air masses. It has been used in many cities, including Beijing (Huang et al., 2010; Sun et al., 2010), Shenzhen (He et al., 2011) and New York City (Sun et al., 2011b), to explore the influence of regional transport on $\mathrm{PM}_{1}$ loading and composition at sampling sites.

The analysis steps in this study are as follows: first, $48 \mathrm{~h}$ back trajectories starting at $200 \mathrm{~m}$ above ground level in Beijing $\left(39.97^{\circ}, 116.37^{\circ}\right)$ were calculated every $6 \mathrm{~h}$ (at $0,6,12$ and 18:00 local time (LT)) throughout the campaign. The trajectories were then clustered according to their similarity in a spatial distribution using the software HYSPLIT4. As a result, a five-cluster solution was adopted because of its small total spatial variance (Fig. 5). Clusters 1-5 represent an increase in pollution from $26.1 \mu \mathrm{g} \mathrm{m}^{-3}$ during the relatively clean cluster 1 to $123 \mu \mathrm{g} \mathrm{m}^{-3}$ during the most polluted time period during cluster 5 . This is because the air masses in each cluster passed over different areas. Cluster 1 originated in the clean area in the north of Beijing and could thus carry clean air from this area. Although the directions of clusters 2 and 3 were similar, their NR-PM 1 mass concentrations were significantly different because their heights were different. Cluster 2 always maintained a higher altitude than did the others before arriving in Beijing and thus did not carry much pollution from the areas it passed over. Cluster 3 was always lower than cluster 2, so it could carry larger amounts of pollutants from the same areas they both passed over. Cluster 4 passed over the Shanxi and Hebei provinces, the largest coal-producing and coal-consuming provinces in China, respectively. Moreover, air masses in this cluster passed over some heavily polluting industrial areas outside of Beijing before arriving at the sampling site (Fig. S-7). These areas contained factories that were moved out of Beijing in 2008 for the 29th Summer Olympic Games. The situation for cluster 5 was similar to that of cluster 4, but not identical. Cluster 5 also passed over the Shanxi and Hebei provinces, and some important cities within these two provinces were located along the trajectory of this cluster, including Taiyuan and Shiji-

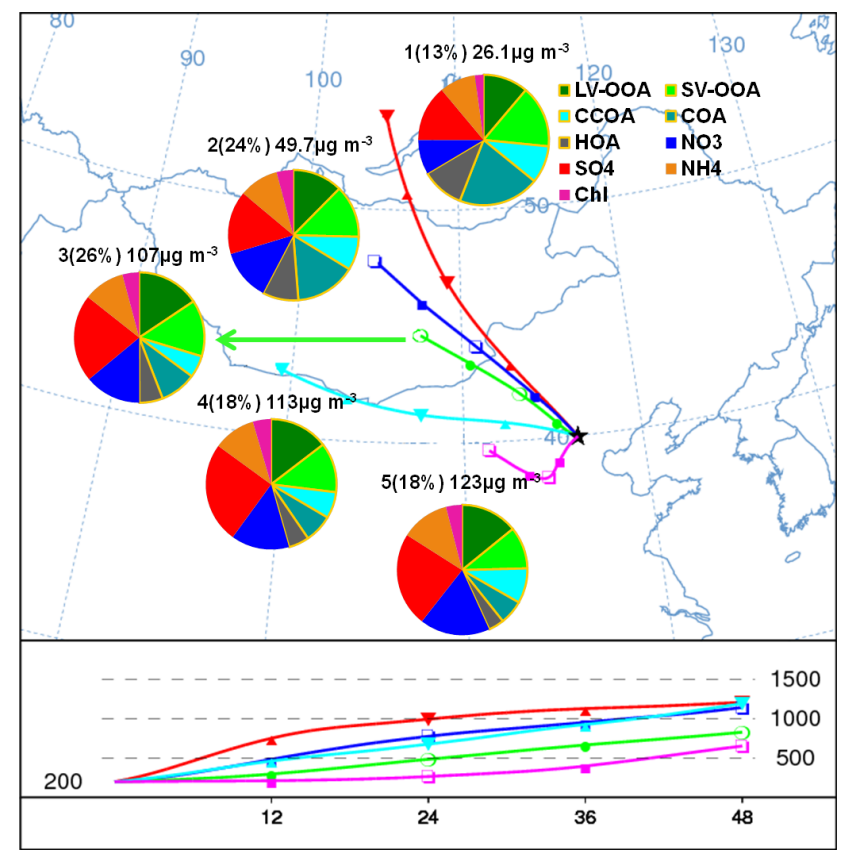

Fig. 5. Back trajectories for each of the identified clusters and corresponding cluster average NR-PM $\mathrm{P}_{1}$ compositions during the campaign.

azhuang, the capital and the main coal consumption cities of these provinces. Therefore, cluster 5 had a mass concentration of CCOA higher than that of cluster $4\left(10.1 \mu \mathrm{g} \mathrm{m}^{-3}\right.$ and $7.7 \mu \mathrm{g} \mathrm{m}^{-3}$, respectively) and contained more pollutants that are typically emitted from cities, such as nitrates. The main precursors of nitrates is $\mathrm{NO}_{\mathrm{x}}$, which is mainly emitted from the transportation in cities. Moreover, the air mass in cluster 5 was highly stagnant compared to the air mass in the other clusters, and the height of the air mass in this cluster was almost always lower than $500 \mathrm{~m}$. The air mass in this cluster could thus carry large amounts of pollutants from heavy pollution areas, and these pollutants were not diluted during transport.

The composition of every species was different in the five clusters. Compared with the other cluster, cluster 1 had the greatest contribution from local, primary aerosol emissions such as CCOA, COA and HOA. In particular, the contribution of COA reached $20 \%$ in cluster 1 . Along the series (cluster $1 \rightarrow$ cluster $2 \rightarrow$ cluster $3 \rightarrow$ cluster $4 \rightarrow$ cluster 5 ), the contribution of local, primary aerosol emissions decreased, while the contributions of some secondary, regional aerosol constituents gradually increased. For example, the contributions of sulfate and nitrate were only $14 \%$ and $9 \%$ in cluster 1 , respectively, while they reached $24 \%$ and $17 \%$, respectively, in cluster 5 . Therefore, the contributions of secondary species increased with that of NR-PM 1 across the clusters. The concentration of NR-PM 1 in cluster 1 was significantly lower than that in cluster 2, possibly because the air in cluster 1 spent a shorter time at a lower height. Difference in 
the light level may also be significant, and this effect should be studied in future research. Compared with other clusters, clusters 1 and 2 contained larger amounts of primary pollutants, and these pollutants were not oxidized due to their short transit time to the sampling site, especially that for cluster 1. Therefore, the contribution of primary species in these clusters were much higher than in the other clusters. Because the other three clusters originated in high-pollution areas and passed over industrial or/and urban areas, they all carried the pollutants emitted in these areas. In these three clusters, the pollutants had enough time in transit to transform into secondary pollutants, and the POA in these clusters was oxidized in transit.

\subsection{Comparison of different periods}

According to the latest ambient air quality standards that were released in 2012 by the Ministry of Environmental Protection (MEP) of the People's Republic of China (http://kjs.mep.gov.cn/hjbhbz/bzwb/dqhjbh/dqhjzlbz/ 201203/t20120302224165.htm), the first and second grades of the $\mathrm{PM}_{2.5}$ daily average mass concentration are $35 \mu \mathrm{g} \mathrm{m}^{-3}$

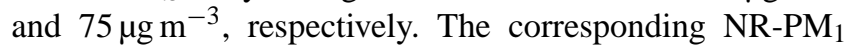
concentrations are $25.9 \mu \mathrm{g} \mathrm{m}^{-3}$ and $55.5 \mu \mathrm{g} \mathrm{m}^{-3}$ (the conversion factor between $\mathrm{PM}_{2.5}$ and NR-PM $\mathrm{PM}_{1}$ is 0.74 , Sun et al., 2013b). The pollution in the month of the campaign was thus divided into three types, by day: days when the daily average mass concentration was lower than $25.9 \mu \mathrm{g} \mathrm{m}^{-3}$, days when it was between $25.9 \mu \mathrm{g} \mathrm{m}^{-3}$ and $55.5 \mu \mathrm{g} \mathrm{m}^{-3}$, and days when it was higher than $55.5 \mu \mathrm{g} \mathrm{m}^{-3}$. To analyze the difference between unpolluted and polluted days, days with an NR-PM

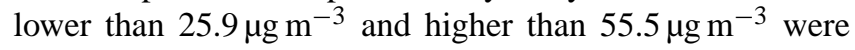
compared in this section.

\subsubsection{Submicron aerosol composition}

Figure 6 presents the average chemical composition of NR$\mathrm{PM}_{1}$ and OA on unpolluted (NR-PM 1 less than $25.9 \mu \mathrm{g} \mathrm{m}^{-3}$ ) and polluted days (NR-PM 1 higher than $55.5 \mu \mathrm{g} \mathrm{m}^{-3}$ ). The average NR-PM ${ }_{1}$ concentration was only $15.7 \mu \mathrm{g} \mathrm{m}^{-3}$ on unpolluted days, while it was approximately 9 times that on polluted days. The organic fraction was the dominant contributor to NR-PM 1 in both two types of days, but its contribution was significantly higher on unpolluted days (58\%) than on polluted days $(41 \%)$. The contributions of all inorganic species, especially the sulfate and nitrate, increased on polluted days. This increase in inorganic species can be explained by the effect of aqueous-phase processing and gas-toparticle partitioning; aqueous-phase processing in particular often occurred during the polluted days due to higher humidity. Under very high RH conditions, water-rich particles and fog droplets are able to capture more soluble gases such as ammonia, nitric acid, $\mathrm{NO}_{\mathrm{x}}$ and $\mathrm{SO}_{2}$, leading to the more efficient production of ammonium nitrate and sulfate (Ge et al., 2012b). Sun et al. (2013a) also found that at elevated RH lev- (a)
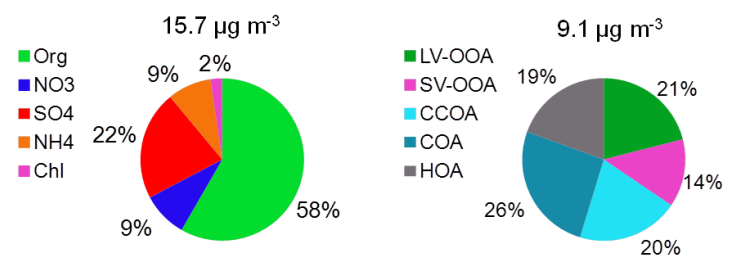

(b)
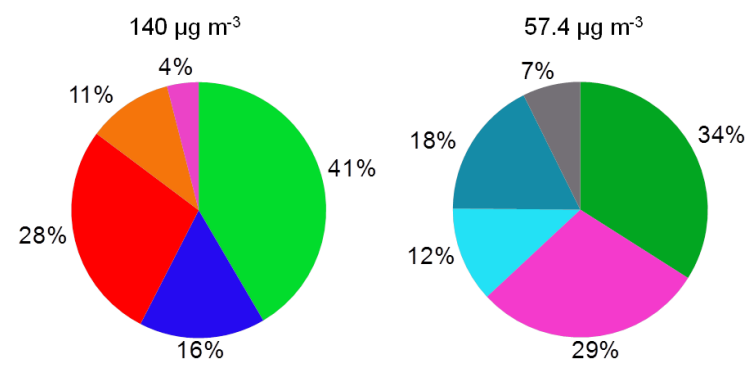

Fig. 6. Average chemical composition of NR-PM 1 and OA for the (a) unpolluted days and (b) polluted days.

els, aqueous-phase processing plays a more significant role and particularly affects sulfate. They estimated that the fog processing of $\mathrm{SO}_{2}$ was responsible for approximately $70 \%$ of sulfate production during wintertime in Beijing (Sun et al., 2013a).

Similar to NR-PM 1 species, the OA components differed significantly between the types of days. The OA concentration was 6 times greater on polluted days than on unpolluted days. The OA composition also differed significantly. POA (CCOA + COA + HOA) dominated the OA composition during the unpolluted days, making up approximately $65 \%$ of the OA, close to the result observed during clean periods in winter in Beijing in $2012(60 \%)$ (Sun et al., 2013b). COA was the most important contributor to OA $(26 \%)$ on unpolluted days, and other two POA types had similar contributions (19\% and 20\%, Fig. 6). On polluted days, the POA fraction was only $37 \%$, and SOA made up $63 \%$ of the OA. The significant increase in SOA can be explained by aqueous-phase processing. Ge et al. (2012b) summarized the mechanism of this phenomenon: the dissolution of water-soluble volatile organic compounds (VOCs) may be enhanced in fog drops and deliquesced particles and the aqueous-phase reactions of these compounds may generate low-volatility species that remain in the particle phases after water evaporates. In addition, aqueous-phase SOA production was observed based on single particle mass spectrometry in a fog event in London (Dall'Osto et al., 2009).

\subsubsection{Diurnal variations in meteorological factors and NR-PM1}

Here, we explored the differences in the diurnal patterns of temperature, relative humidity $(\mathrm{RH})$, wind speed, wind direction and air pressure between the types of days. The diurnal variation of every factor in the entire period was also 
added to the comparison as a reference (Fig. 7a). During the unpolluted days, temperature and humidity were lower than on polluted days; the average temperature on unpolluted and polluted days was $-4.3^{\circ} \mathrm{C}$ and $-2.2^{\circ} \mathrm{C}$, respectively, and the average humidity was $25.5 \%$ and $61.6 \%$, respectively. In particular, the higher humidity on polluted days caused the moisture content in the particles to increase, which subsequently enhanced the absorption capacity of the particles for semi-volatile and volatile organic matter and ultimately led to elevated OA mass concentrations (Ge et al., 2012b). This is demonstrated in Fig. 1, which shows that the humidity remained at approximately $80 \%$ during several serious pollution events, such as from 22 January to 23 and from 25 January to 28 . The contribution of inorganic species increased rapidly during these periods. The wind speed and air pressure were lower on the polluted days (Fig. 7a). Our results show a consistent set of meteorological conditions on the polluted days: the wind speed was relatively low $\left(1.1 \mathrm{~m} \mathrm{~s}^{-1}\right)$, the temperature increased and the air pressure remained low. In this case, a strong temperature inversion at low altitudes was often accompanied by a highly stable atmospheric layer. This process made the ground convergence stronger, thus preventing the diffusion of pollutants and causing the atmospheric pollutants in the region surrounding to Beijing to converge towards the centre. This aggravated the degree of air pollution in the city (Liu et al., 2012). In addition, the wind directions also differed between the types of days. Here, we mainly considered the wind direction after 09:00 because the the wind speed was lower before 09:00. The wind direction on polluted days was from the south, allowing for the transport of large amounts of pollutants from the area south of Beijing. However, the wind direction on unpolluted days was unstable, including northwest and north winds that passed over some clean areas, and were likely conducive to the dilution and removal of the pollutants in Beijing. This is consistent with the results of back trajectory clustering analysis.

Figure $7 \mathrm{~b}$ shows the diurnal profiles of NR-PM 1 species and OA components on the two types of days and the entire period. In this study, the overall trends for organics on unpolluted days and polluted days were similar, with peaks at noon (12:00-14:00) and in the evening (18:00-24:00). For both, the second peak was much larger than the noon peak, and its duration was longer. The noon period and the period from 18:00-20:00 correspond to the peak dining periods. Additionally, the height of the mixing layer is lower in the evening, a condition that is conducive to the accumulation of pollutants in the atmosphere. The combined effect of cooking emissions and a lower mixing layer resulted in the higher organic concentration and longer duration observed in the evening. This trend is consistent with other studies in Beijing (Sun et al., 2010; Huang et al., 2010) but differs from the trend observed in foreign urban locations, for example, Pittsburgh (Zhang et al., 2005a) and New York City (Drewnick et al., 2004), where a morning peak of organics that corresponds to morning traffic is typically observed.
The diurnal profiles of the concentrations of major secondary inorganic species (sulfate, nitrate, and ammonium) on unpolluted days were almost flat compared to those observed over the entire period and polluted days (Fig. 7b). For example, the daily concentration increment of sulfate on unpolluted days was only approximately $1.9 \mu \mathrm{g} \mathrm{m}^{-3}$, while the average increment over the entire period reached approximately $10 \mu \mathrm{g} \mathrm{m}^{-3}$. The lowest concentrations of sulfate, nitrate, and ammonium over the entire period occurred from 07:00-08:00, and the corresponding concentrations were $15.4 \mu \mathrm{g} \mathrm{m}^{-3}, 8.2 \mu \mathrm{g} \mathrm{m}^{-3}$, and $6.2 \mu \mathrm{g} \mathrm{m}^{-3}$, respectively. The concentrations of all three then increased gradually, reaching their peak values between 19:00 and 20:00, when the concentrations were $23.6 \mu \mathrm{g} \mathrm{m}^{-3}, 17.3 \mu \mathrm{g} \mathrm{m}^{-3}$, and $11.5 \mu \mathrm{g} \mathrm{m}^{-3}$, respectively. This result differs significantly from the results obtained in summer in Beijing. For example, Huang et al. (2010) found that the concentration of sulfate and ammonium were relatively stable over a $24 \mathrm{~h}$ period in summer, except for a slight, continuous increase in the afternoon. They also observed the lowest concentrations of nitrate in the afternoon. This seasonal difference is likely caused by the combined effect of gas-to-particle partitioning and aqueousphase processing, which is facilitated by the relatively lower temperature and higher $\mathrm{RH}$ at night and the frequent occurrence of nighttime fogs in winter in Beijing. A lower mixed layer depth and calm wind at night may have also contributed to the accumulation of these species (Ge et al., 2012b).

The observed diurnal profile of chloride had a large amplitude over the entire period; its concentration peaked around midnight and remained low during the daytime, unlike the other three inorganic species. The different diurnal cycles of chloride and nitrate observed in this study indicate that they have different sources and formation mechanisms. Direct emissions from coal combustion are a major source of chloride in winter, and therefore, the diurnal cycles of chloride and coal combustion OA are very similar (discussed later), further supporting this conclusion.

LV-OOA showed a pronounced diurnal cycle over the entire period, with its concentration increasing from $7.6 \mu \mathrm{g} \mathrm{m}^{-3}$ at $8: 00$ to $17.5 \mu \mathrm{g} \mathrm{m}^{-3}$ at $16: 00$, reflecting the importance of photochemical production during the daytime. The diurnal variation of SV-OOA over the entire period showed a large concentration decease in the daytime, which was likely the result of both its semi-volatility and the high PBL height in the daytime. Aqueous-phase production during high-humidity conditions also affects the diurnal variation of OOA at night. The variation trend of CCOA over the entire period was similar to that of chloride. The lowest concentration occurred in the early morning, and the concentration then increased slowly all day (Fig. 7b). The highest value appeared at 22:00. This diurnal cycle is consistent with the source emissions: the higher level of CCOA at night reflects heating activities, which are intensified during the night and decreased during the day. HOA showed a pronounced morning peak that was associated with traffic emissions over 
(a)

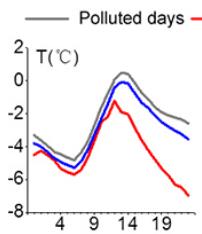

(b)

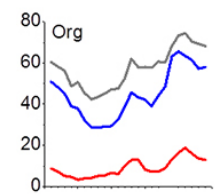

${ }^{40}$ LV-OOA

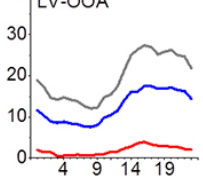

(c)

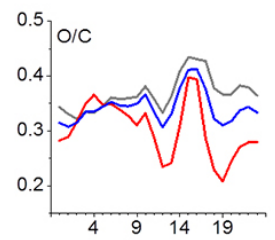

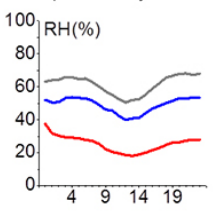

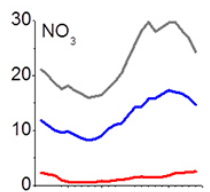

${ }^{30}$ SV-OOA
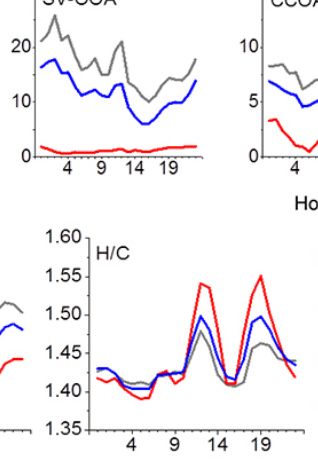

${ }^{15}$ CCOA

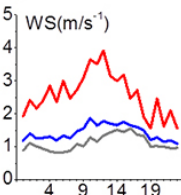

Hour of day
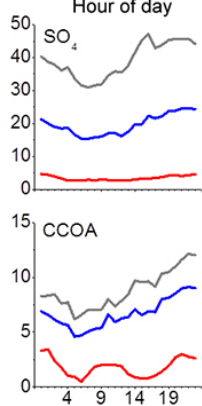

Hour of day

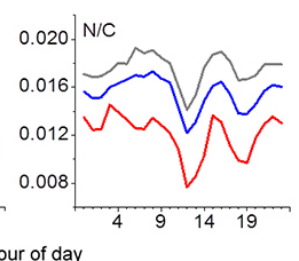

25. $\mathrm{COA}$
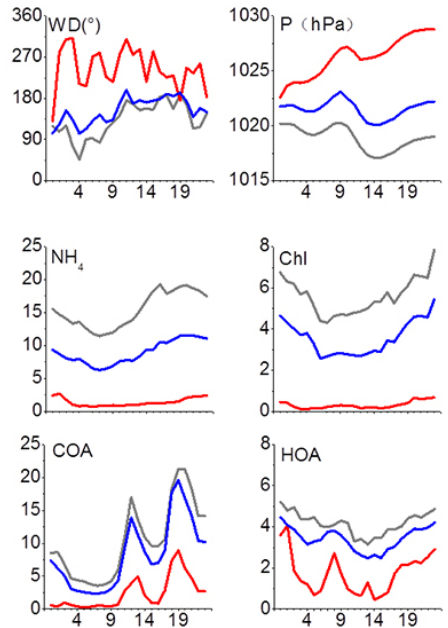

${ }^{8}$ HOA

6
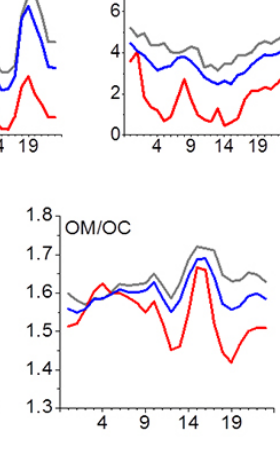

Fig. 7. Diurnal profiles of (a) meteorological factors; (b) NR-PM1 species and OA components; and (c) O/C, H/C, N/C and OM/OC ratios for the polluted days, entire period, and unpolluted days.

the entire period, with the highest concentration appearing at 0:00 and the lowest appearing at 15:00. Overall, the concentration of HOA was higher at night than during the day. A similar result was found in 2012 for winter in Beijing (Sun et al., 2013b). This result suggests that the HOA concentration is driven by traffic emissions from heavy-duty diesel trucks (HDDT) and other heavy-duty vehicles (HDV) that are not allowed inside the city between 06:00 and 22:00.

Figure $7 \mathrm{c}$ shows the diurnal variations in the $\mathrm{O} / \mathrm{C}, \mathrm{H} / \mathrm{C}$, $\mathrm{N} / \mathrm{C}$ and $\mathrm{OM} / \mathrm{OC}$ ratios in different periods. The trends of the four ratios on the two types of days and over the entire period were similar. However, the difference in all of these ratios except the $\mathrm{N} / \mathrm{C}$ ratio across the three periods was significant in the daytime. These ratios reflect the oxidation of the aerosol, which is mainly affected by daytime photochemical processes. The degree of oxidation of aerosol on polluted days was obviously higher than on unpolluted days because (1) the temperature on polluted days was higher and thus conducive to the oxidation of aerosols; (2) the weather conditions on these days were not conducive to the spread of pollutants and would keep them in the atmosphere longer, providing more time for the oxidation of aerosols; and (3) fog processing in the polluted days is conducive the oxidation of OA. This conclusion was also reached by Ge et al. (2012b), who observed that SOA produced in the aqueous phase was generally more oxygenated than SOA formed in the gas phase, thereby producing a decrease in the average $\mathrm{H} / \mathrm{C}$ ratio.

Figure 8 shows statistical results concerning the contribution of each cluster on polluted and unpolluted days. Clean cluster 1 was the most important cluster during the unpolluted days, accounting for $71 \%$ of the total back trajectory (BT), followed by clusters $2(19 \%)$ and $3(10 \%)$. There was no contribution from clusters 4 and 5, which had higher NR$\mathrm{PM}_{1}$ mass concentrations, on unpolluted days. The opposite phenomenon was observed during the polluted days. The contribution of cluster 1 was only $2 \%$, while clusters 3,4 , and 5 contributed $30 \%, 28 \%$ and $27 \%$ to the total all BT, respectively.

\subsubsection{Particle acidity}

Understanding acidity in atmospheric particles is important because acidity is a key parameter that affects aerosol hygroscopic growth, toxicity, and heterogeneous reactions (Sun et al., 2010). We evaluated the acidity of submicron aerosols using $\mathrm{NH}_{4}^{+}$meas $/ \mathrm{NH}_{4}^{+}$pred, i.e., the ratio of the measured $\mathrm{NH}_{4}^{+}$concentration to the predicted $\mathrm{NH}_{4}^{+}$required to fully neutralize the measured $\mathrm{SO}_{4}^{2-}, \mathrm{NO}_{3}^{-}$, and $\mathrm{Cl}^{-}$(Zhang et al., 2007). Particles are considered to be "more acidic" if the measured $\mathrm{NH}_{4}^{+}$concentration is significantly (by $25 \%$ or more) lower than the predicted $\mathrm{NH}_{4}^{+}$concentration and to 


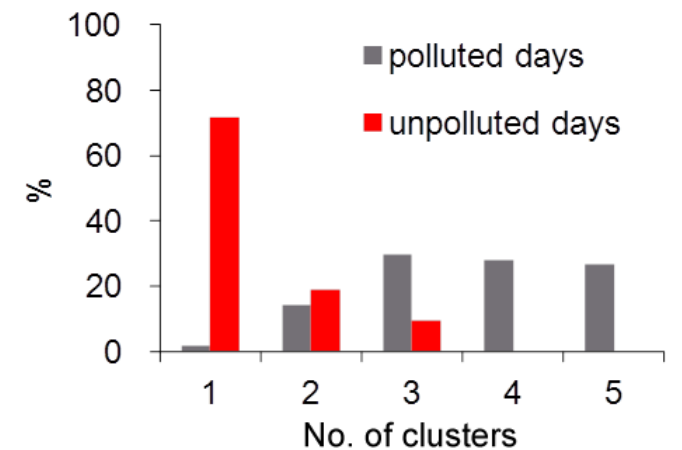

Fig. 8. The contribution of every cluster on polluted days and unpolluted days.

be "bulk neutralized" if the two values are similar (Zhang et al., 2005a).

The correlations between the measured and predicted $\mathrm{NH}_{4}^{+}$on polluted days, over the entire period, and on unpolluted days were very strong $\left(R^{2}=0.99,0.99\right.$ and 0.99 , respectively), with regression slopes of approximately 0.66 , 0.68 and 0.74 , respectively (Fig. 9), indicating that NR-PM in Beijing was acidic for both types of days and over the entire period. However, the acidity of NR-PM 1 on polluted days was greater than that on unpolluted days. This difference was mainly caused by the uptake of $\mathrm{SO}_{2}$ and further aqueousphase oxidation on polluted days, both of which can increase aerosol particle acidity (Sun et al., 2013a). Sun et al. (2006) also found that the aerosol particles were acidic and could not be fully neutralized during an intense haze-fog episode in the winter of 2004 in Beijing. Similarly, approximately $60 \%$ of the cloud water samples collected at Mountain Tai in the North China Plain had pH values between 3 and 5, which were largely due to rapid oxidation of high concentration of $\mathrm{SO}_{2}$ in clouds (Shen et al., 2012).

The acidity over the entire period was much greater than it was in 2012 at a similar site because the contribution of sulfate in 2013 was much higher than that in 2012; the sulfate contribution was $22 \%$ in 2013 and $14 \%$ in 2012 (Sun et la., 2013b). However, the contribution of ammonium in 2012 $(13 \%)$ was higher than it was in our study $(10 \%)$. This difference in composition likely caused the change in aerosol acidity between these two years. Sun et al. (2010) found the regression slope between the measured and predicted $\mathrm{NH}_{4}^{+}$ to be approximately 1.01 in summer in Beijing in 2006, implying that aerosol was bulk neutralized. This result could be different from ours because of the massive emission of $\mathrm{SO}_{2}$ from coal combustion in our study, whereas this source of $\mathrm{SO}_{2}$ is greatly reduced in summer.

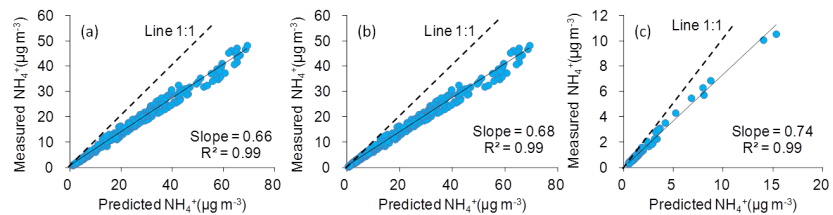

Fig. 9. Scatter plot that compares predicted $\mathrm{NH}_{4}^{+}$vs. measured $\mathrm{NH}_{4}^{+}$for (a) polluted days; (b) entire periods; and (c) unpolluted days.

\subsection{Chemically resolved PM pollution}

Figure 10 shows the variations in the mass concentrations and mass fractions of NR-PM 1 species and OA components as a function of NR-PM $M_{1}$ mass. A similar analysis for data obtained in winter in Beijing in 2012 was represented by Sun et al. (2013b), and the highest NR-PM 1 mass concentration reported in their study was approximately $210 \mu \mathrm{g} \mathrm{m}^{-3}$. Therefore, we divided the NR-PM $\mathrm{PM}_{1}$ mass concentration into two ranges: lower than $210 \mu \mathrm{g} \mathrm{m}^{-3}$ (the non-grey background area in Fig. 10) and higher than $210 \mu \mathrm{g} \mathrm{m}^{-3}$ (the grey background area in Fig. 10). We chose this division for two reasons: (1) to compare our data with the results from 2012 because the 2012 site was very close to ours and both studies were conducted in winter and (2) to analyze the variation trends when the NR-PM 1 level is higher than $210 \mu \mathrm{g} \mathrm{m}^{-3}$. These two NR-PM $\mathrm{PM}_{1}$ mass ranges are referred to as "lower NR-PM 1 mass level" and "higher NR-PM ${ }_{1}$ mass level" to facilitate comparison. The variation trends were more dramatic at the higher NR-PM 1 mass level, which have not been observed in 2012. Therefore, this division is not only beneficial for comparing the results from the two years but also conducive to the analysis of new trends.

Figure 10a shows that all aerosol species except COA and HOA showed a monotonic and almost linear increase with the increase of PM loading in the lower NR-PM 1 mass level, consistent with the results observed in winter in Beijing 2012 (Sun et al., 2013b). The variation trends of several species were significant different at the higher NR-PM $\mathrm{PM}_{1}$ mass level. At the higher NR-PM 1 mass level, the variation trends of the organics, LV-OOA and three inorganic species (sulfate, nitrate and ammonium) were similar to those of the lower NR$\mathrm{PM}_{1}$ level. However, chloride and the other four OA components (SV-OOA, CCOA, COA and HOA) showed a dramatic difference with increased NR-PM 1 loading. This finding indicates that the total organics and three important inorganic species (sulfate, nitrate and ammonium) will always increase with increased PM loading. The other components will monotonically and almost linearly increase with PM loading in the lower NR-PM 1 loading range, but their variation trends will be different in the higher NR-PM 1 loading range.

Figure 10b shows that although the mass concentrations of aerosol species varied significantly as a function of PM 

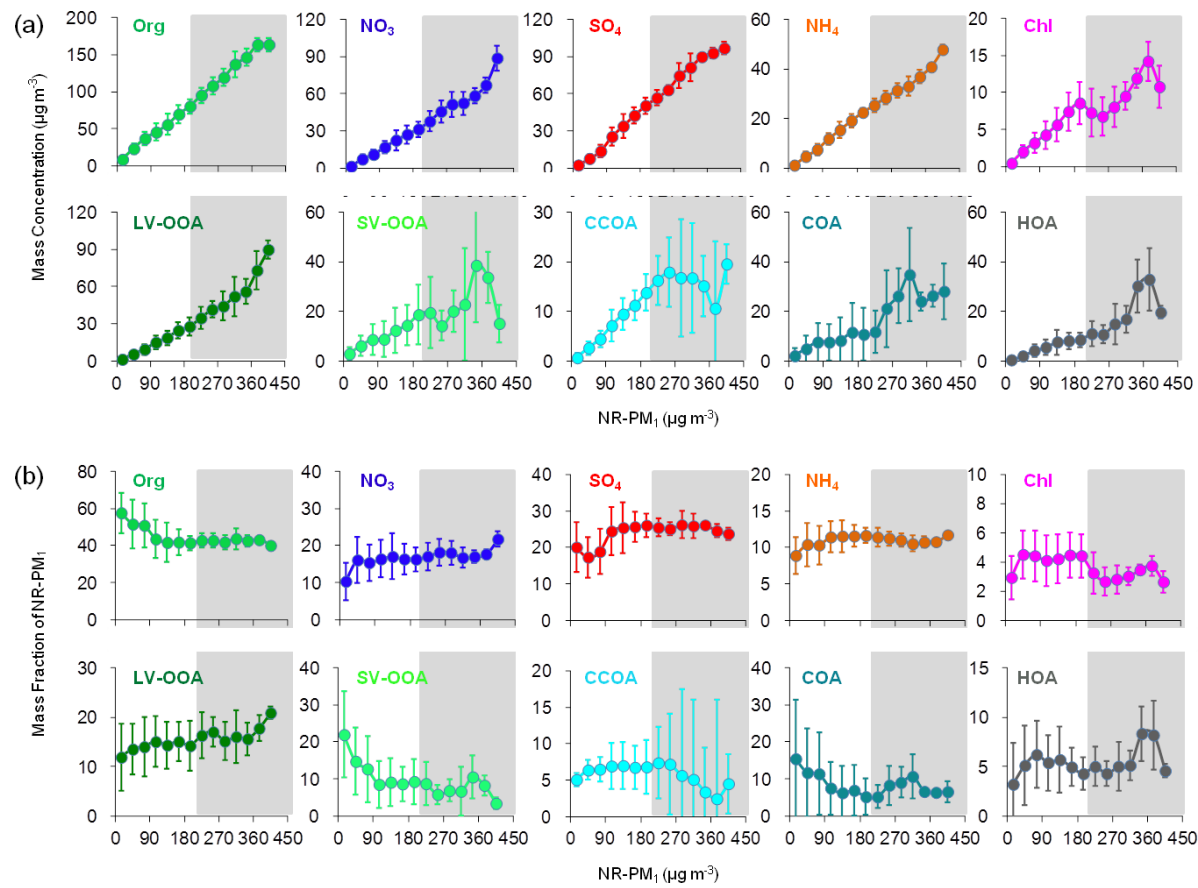

Fig. 10. Variation of (a) mass concentration and (b) mass fractions of NR-PM 1 species and OA components as a function of NR-PM 1 mass loadings. The data were binned according to the total NR-PM 1 mass, and the vertical lines are the standard deviation.

loading, the contribution of organic and inorganic species to the total NR-PM 1 mass did not show a significant NR$\mathrm{PM}_{1}$ mass loading dependency. This finding indicates that the higher NR-PM 1 pollution in winter is a result of the synergistic effect of all pollutants, consistent with results obtained in 2012 (Sun et al., 2013b). Organics had the highest contribution (40-60\%) to NR-PM 1 pollution across different mass loadings levels, and the inorganic species, sulfate, nitrate, and ammonium, contributed 15-25\%, 10-20\%, and $8-12 \%$ to the total NR-PM ${ }_{1}$ mass, respectively. This is quite different from results observed in summer, particularly for nitrate (Sun et al., 2012). In summer, the nitrate contribution increased significantly with NR-PM 1 loading, highlighting the important role of nitrate in NR-PM $\mathrm{P}_{1}$ pollution. In winter, however, nitrate displayed an approximately stable contribution as the NR-PM 1 mass loading increased. This difference may be due to the different photochemical production rate, $\mathrm{RH}$ and temperature influences on gas-particle partitioning (Ranjan et al., 2012), as well as on $\mathrm{NH}_{3}$ ambient levels (Meng et al., 2011). The sulfate contribution is elevated but stable when NR-PM ${ }_{1}$ is at the higher level, indicating that additional production of sulfate occurs during high PM episodes. The aqueous production of sulfate, for example, is an important source of sulfate in winter that may be increased in high-pollution periods (Ge et al., 2012b; Sun et al., 2013b).The contribution of chloride was found to be decreased when the NR-PM 1 loading at the higher level, consistent with the observed variation in chloride concentration with mass loading.
OA components vary widely with NR-PM 1 mass loading. LV-OOA always maintained a stable, increasing trend with increased mass loading, and its contribution was significantly increased when the NR-PM $\mathrm{P}_{1}$ was at the higher mass level. The contribution of SV-OOA, however, decreased sharply when the NR-PM 1 loading was either lower than $120 \mu \mathrm{g} \mathrm{m}^{-3}$ or higher than $360 \mu \mathrm{g} \mathrm{m}^{-3}$. This finding suggests that the aerosol was increasingly aged with increased NR-PM $\mathrm{PM}_{1}$ mass loading. The contribution of CCOA was stable at the lower NR-PM ${ }_{1}$ mass level, but it decreased at the higher NR-PM mass level, consistent with the observed trend of CCOA mass at the higher NR-PM 1 mass level. This variation is similar to the trend observed for chloride, indicating that the contribution of coal combustion was decreased when the NR-PM was at the higher mass level. The highest COA contribution occurred during the lowest NR-PM 1 level, and it generally decreased with increased NR-PM ${ }_{1}$ loading, despite a small increase at the higher NR-PM $M_{1}$ mass level. The highest COA contribution at the lowest NR-PM 1 mass level was higher than the contribution of LV-OOA, CCOA and HOA (only SVOOA's contribution was higher), suggesting that COA was a very important OA component on unpolluted days. The contribution of HOA remained low, though a small increase was observed when the NR-PM 1 was higher than $360 \mu \mathrm{g} \mathrm{m}^{-3}$. 


\section{Conclusions}

Non-refractory submicron particles $\left(\mathrm{NR}-\mathrm{PM}_{1}\right)$ were measured in situ using a high-resolution time-of-flight aerosol mass spectrometer during a serious pollution month (January 2013) in an intensive field study in Beijing. On average, the contribution of organics to the total NR-PM 1 in winter was higher than in summer; organics comprised $50 \%$ of the total mass, followed by sulfate ( $22 \%$ ), nitrate $(14 \%)$, ammonium $(10 \%)$, and chloride $(4 \%)$. The average size distributions of all components were very similar and were characterized by a prominent accumulation mode peaking at $600 \mathrm{~nm}$. The organics and nitrate were also characterized by an additional smaller mode at approximately $200 \mathrm{~nm}$. Calculations of the organic elemental composition indicated that, on average, $\mathrm{C}$, $\mathrm{H}, \mathrm{O}$ and $\mathrm{N}$ contributed $73.6 \%, 7.2 \%, 16.5 \%$ and $2.8 \%$ of the total atomic numbers of OA, respectively, corresponding to an $\mathrm{OM} / \mathrm{OC}$ ratio of 1.60 .

Positive matrix factorization (PMF) analyses of this highresolution organic mass spectral data found that the two oxygenated organic aerosols (LV-OOA and SV-OOA) are the most important $\mathrm{OA}$ components, together accounting for $54 \%$ of the total organic mass. Cooking-related OA (COA) is the most important primary OA component, with a contribution of approximately $20 \%$. A coal combustion OA (CCOA) that was not observed in summer was identified in winter; this component is mainly derived from coal combustion. The other OA component was HOA, which is closely associated with primary combustion sources. Back trajectory clustering analysis indicated that the direction of air masses in winter was very different than that in summer. Air masses from the south were found to contain aerosols with a dominant fraction of secondary inorganic and organic species. However, air masses from the north were dominated by organic material, most of which was produced by primary CCOA, COA and HOA sources.

After an in-depth comparison, we found that some aerosol characteristics were different on polluted days compared to unpolluted days: (1) the diurnal variation of NR-PM species showed a different trend on polluted days, reaching higher values from afternoon to midnight; (2) the contribution of inorganic species and SOA components were all increased significantly on polluted days, most likely due to aqueousphase processing and unfavorable meteorological factors; (3) the variation of every NR-PM ${ }_{1}$ species and all OA components was more dramatic when the total NR-PM 1 mass concentration was at a higher level; and (4) aerosol acidity was greater and the air mass was transported mainly from high-pollution areas on polluted days. The serious pollution in the study month can be attributed to the synergy of unfavorable meteorological factors, such as the lower wind speed, higher RH, and higher temperature, the transport of air masses from highly polluted areas, emissions from local sources, and other factors.

\section{Supplementary material related to this article is available online at http://www.atmos-chem-phys.net/14/ 2887/2014/acp-14-2887-2014-supplement.pdf.}

Acknowledgements. This study was supported by the "Strategic Priority Research Program" of the Chinese Academy of Sciences (XDA05100100 \& XDB05020000) and the National Natural Science Foundation of China (no. 41230642, 41175107 and 41275139). We gratefully acknowledge this financial support.

Edited by: D. Covert

\section{References}

Aiken, A. C., DeCarlo, P. F., Kroll, J. H., Worsnop, D. R., Huffman,, J. A., D., K. S., Ulbrich, I. M., Mohr, C., Kimmel,, J. R., S., D., Sun, Y., Zhang, Q., Trimborn, A., Northway,, M., Z., P. J., Canagaratna, M. R., Onasch, T. B., Alfarra,, M. R., P., A. S. H., Dommen, J., Duplissy, J., Metzger, A.,, and Baltensperger, U., and Jimenez, J. L.: O/C and OM/OC ratios of primary, secondary, and ambient organic aerosols with High-Resolution Time-of-Flight Aerosol Mass Spectrometry, Environ. Sci. Technol., 42, 4478-4485, 2008.

Aiken, A. C., Salcedo, D., Cubison, M. J., Huffman, J. A., DeCarlo, P. F., Ulbrich, I. M., Docherty, K. S., Sueper, D., Kimmel, J. R., Worsnop, D. R., Trimborn, A., Northway, M., Stone, E. A., Schauer, J. J., Volkamer, R. M., Fortner, E., de Foy, B., Wang, J., Laskin, A., Shutthanandan, V., Zheng, J., Zhang, R., Gaffney, J., Marley, N. A., Paredes-Miranda, G., Arnott, W. P., Molina, L. T., Sosa, G., and Jimenez, J. L.: Mexico City aerosol analysis during MILAGRO using high resolution aerosol mass spectrometry at the urban supersite (T0) - Part 1: Fine particle composition and organic source apportionment, Atmos. Chem. Phys., 9, 6633-6653, doi:10.5194/acp-9-6633-2009, 2009.

Alfarra, M. R., Prevot, A. S. H., Szidat, S., Sandradewi, J., Weimer, S., Lanz, V. A., Scheriber, D., Mohr, M., and Baltensperger, U.: Identification of the mass spectral signature of organic aerosols from wood burning emissions, Environ. Sci. Technol., 41, 5770 5777, 2007.

Canagaratna, M. R., Jayne, J. T., Jimenez, J. L., Allan, J. D., Alfarra, M. R., Zhang, Q., Onasch, T. B., Drewnick, F., Coe, H., Middlebrook, A., Delia, A., Williams, L. R., Trimborn, A. M., Northway, M. J., DeCarlo, P. F., Kolb, C. E., Davidovits, P., and Worsnop, D. R.: Chemical and microphysical characterization of ambient aerosols with the aerodyne aerosol mass spectrometer, Mass Spectrom. Rev., 26, 185-222, doi:10.1002/mas.20115, 2007.

Dall'Osto, M., Harrison, R. M., Coe, H., and Williams, P.: Real-time secondary aerosol formation during a fog event in London, Atmos. Chem. Phys., 9, 2459-2469, doi:10.5194/acp-9-2459-2009, 2009.

DeCarlo, P. F., Kimmel, J. R., Trimborn, A., Northway, M. J., Jayne, J. T., Aiken, A. C., Gonin, M., Fuhrer, K., Horvath, T., Docherty, K. S., Worsnop, D. R., and Jimenez, J. L.: Field-Deployable, High-Resolution, Time-of-Flight Aerosol Mass Spectrometer, Anal. Chem., 78, 8281-8289, 2006. 
DeCarlo, P. F., Ulbrich, I. M., Crounse, J., de Foy, B., Dunlea, E. J., Aiken, A. C., Knapp, D., Weinheimer, A. J., Campos, T., Wennberg, P. O., and Jimenez, J. L.: Investigation of the sources and processing of organic aerosol over the Central Mexican Plateau from aircraft measurements during MILAGRO, Atmos. Chem. Phys., 10, 5257-5280, doi:10.5194/acp-10-52572010, 2010.

Drewnick, F., Schwab, J. J., Jayne, J. T., Canagaratna, M., Worsnop, D. R., and Demerjian, K. L.: Measurement of Ambient Aerosol Composition During the PMTACS-NY 2001 Using an Aerosol Mass Spectrometer. Part I: Mass Concentrations Special Issue ofAerosol Science and Technologyon Findings from the Fine Particulate Matter Supersites Program, Aerosol Sci. Tech., 38, 92-103, 2004.

Drewnick, F., Hings, S. S., DeCarlo, P., Jayne, J. T., Gonin, M., Fuhrer, K., Weimer, S., Jimenez, J. L., Demerjian, K. L., Borrmann, S., and Worsnop, D. R.: A New Time-of-Flight Aerosol Mass Spectrometer (TOF-AMS) - Instrument Description and First Field Deployment, Aerosol Sci. Tech., 39, 637-658, 2005.

Ge, X. L., Setyan, A., Sun, Y., and Zhang, Q.: Primary and secondary organic aerosols in Fresno, California during wintertime: results from high resolution aerosol mass spectrometry, J. Geophys. Res.-Atmos., 117, D19301, doi:10.1029/2012jd018026, 2012a.

Ge, X. L., Zhang, Q., Sun, Y. L., Ruehl, C. R., and Setyan, A.: Effect of aqueous-phase processing on aerosol chemistry and size distributions in Fresno, California, during wintertime, Environ. Chem., 9, 221-235, doi:10.1071/EN11168, 2012b.

Hallquist, M., Wenger, J. C., Baltensperger, U., Rudich, Y., Simpson, D., Claeys, M., Dommen, J., Donahue, N. M., George, C., Goldstein, A. H., Hamilton, J. F., Herrmann, H., Hoffmann, T., Iinuma, Y., Jang, M., Jenkin, M. E., Jimenez, J. L., Kiendler-Scharr, A., Maenhaut, W., McFiggans, G., Mentel, Th. F., Monod, A., Prévôt, A. S. H., Seinfeld, J. H., Surratt, J. D., Szmigielski, R., and Wildt, J.: The formation, properties and impact of secondary organic aerosol: current and emerging issues, Atmos. Chem. Phys., 9, 5155-5236, doi:10.5194/acp-9-51552009, 2009

He, L.-Y., Lin, Y., Huang, X.-F., Guo, S., Xue, L., Su, Q., Hu, M., Luan, S.-J., and Zhang, Y.-H.: Characterization of highresolution aerosol mass spectra of primary organic aerosol emissions from Chinese cooking and biomass burning, Atmos. Chem. Phys., 10, 11535-11543, doi:10.5194/acp-10-11535-2010, 2010.

He, L. Y., Huang, X. F., Xue, L., Hu, M., Lin, Y., Zheng, J., Zhang, R., and Zhang, Y. H.: Submicron aerosol analysis and organic source apportionment in an urban atmosphere in Pearl River Delta of China using high-resolution aerosol mass spectrometry, J. Geophys. Res.-Atmos., 116, D12304, doi:10.1029/2010jd014566, 2011.

Heald, C. L., Kroll, J. H., Jimenez, J. L., Docherty, K. S., DeCarlo, P. F., Aiken, A. C., Chen, Q., Martin, S. T., Farmer, D. K., and Artaxo, P.: A simplified description of the evolution of organic aerosol composition in the atmosphere, Geophys. Res. Lett., 37, L08803, doi:10.1029/2010g1042737, 2010.

Hildebrandt, L., Engelhart, G. J., Mohr, C., Kostenidou, E., Lanz, V. A., Bougiatioti, A., DeCarlo, P. F., Prevot, A. S. H., Baltensperger, U., Mihalopoulos, N., Donahue, N. M., and Pandis, S. N.: Aged organic aerosol in the Eastern Mediterranean: the Finokalia Aerosol Measurement Experiment - 2008, Atmos.
Chem. Phys., 10, 4167-4186, doi:10.5194/acp-10-4167-2010, 2010.

Hu, W. W., Hu, M., Yuan, B., Jimenez, J. L., Tang, Q., Peng, J. F., Hu, W., Shao, M., Wang, M., Zeng, L. M., Wu, Y. S., Gong, Z. H., Huang, X. F., and He, L. Y.: Insights on organic aerosol aging and the influence of coal combustion at a regional receptor site of central eastern China, Atmos. Chem. Phys., 13, 10095-10112, doi:10.5194/acp-13-10095-2013, 2013.

Huang, X.-F., He, L.-Y., Hu, M., Canagaratna, M. R., Sun, Y., Zhang, Q., Zhu, T., Xue, L., Zeng, L.-W., Liu, X.-G., Zhang, Y.-H., Jayne, J. T., Ng, N. L., and Worsnop, D. R.: Highly time-resolved chemical characterization of atmospheric submicron particles during 2008 Beijing Olympic Games using an Aerodyne High-Resolution Aerosol Mass Spectrometer, Atmos. Chem. Phys., 10, 8933-8945, doi:10.5194/acp-10-8933-2010, 2010.

Huang, X.-F., He, L.-Y., Hu, M., Canagaratna, M. R., Kroll, J. H., Ng, N. L., Zhang, Y.-H., Lin, Y., Xue, L., Sun, T.-L., Liu, X.-G., Shao, M., Jayne, J. T., and Worsnop, D. R.: Characterization of submicron aerosols at a rural site in Pearl River Delta of China using an Aerodyne High-Resolution Aerosol Mass Spectrometer, Atmos. Chem. Phys., 11, 1865-1877, doi:10.5194/acp-11-18652011, 2011.

Huang, X.-F., He, L.-Y., Xue, L., Sun, T.-L., Zeng, L.-W., Gong, Z.-H., Hu, M., and Zhu, T.: Highly time-resolved chemical characterization of atmospheric fine particles during 2010 Shanghai World Expo, Atmos. Chem. Phys., 12, 4897-4907, doi:10.5194/acp-12-4897-2012, 2012.

Jayne, J. T., Leard, D. C., Zhang, X., Davidovits, P., Smith, K. A. Kolb, C. E., and Worsnop, D. R.: Development of an Aerosol Mass Spectrometer for Size and Composition Analysis of Submicron Particles, Aerosol. Sci. Tech., 33, 49-70, 2000.

Jimenez, J. L., Jayne, J. T., Shi, Q., Kolb, C. E., Worsnop, D. R. Yourshaw, I., Seinfeld, J. H., Flagan, R. C., Zhang, X. F., Smith, K. A., Morris, J. W., and Davidovits, P: Ambient aerosol sampling using the Aerodyne Aerosol Mass Spectrometer, J. Geophys. Res.-Atmos., 108, 8425, doi:10.1029/2001jd001213, 2003.

Jimenez, J. L., Canagaratna, M. R., Donahue, N. M., Prevot, A. S., Zhang, Q., Kroll, J. H., DeCarlo, P. F., Allan, J. D., Coe, H., Ng, N. L., Aiken, A. C., Docherty, K. S., Ulbrich, I. M., Grieshop, A. P., Robinson, A. L., Duplissy, J., Smith, J. D., Wilson, K. R., Lanz, V. A., Hueglin, C., Sun, Y. L., Tian, J., Laaksonen, A., Raatikainen, T., Rautiainen, J., Vaattovaara, P., Ehn, M., Kulmala, M., Tomlinson, J. M., Collins, D. R., Cubison, M. J., Dunlea, E. J., Huffman, J. A., Onasch, T. B., Alfarra, M. R., Williams, P. I., Bower, K., Kondo, Y., Schneider, J., Drewnick, F., Borrmann, S., Weimer, S., Demerjian, K., Salcedo, D., Cottrell, L., Griffin, R., Takami, A., Miyoshi, T., Hatakeyama, S., Shimono, A., Sun, J. Y., Zhang, Y. M., Dzepina, K., Kimmel, J. R., Sueper, D., Jayne, J. T., Herndon, S. C., Trimborn, A. M., Williams, L. R., Wood, E. C., Middlebrook, A. M., Kolb, C. E., Baltensperger, U., and Worsnop, D. R.: Evolution of organic aerosols in the atmosphere, Science, 326, 1525-1529, doi:10.1126/science.1180353, 2009.

Lanz, V. A., Alfarra, M. R., Baltensperger, U., Buchmann, B., Hueglin, C., and Prévôt, A. S. H.: Source apportionment of submicron organic aerosols at an urban site by factor analytical modelling of aerosol mass spectra, Atmos. Chem. Phys., 7, 15031522, doi:10.5194/acp-7-1503-2007, 2007. 
Lanz, V. A., Prévôt, A. S. H., Alfarra, M. R., Weimer, S., Mohr, C., DeCarlo, P. F., Gianini, M. F. D., Hueglin, C., Schneider, J., Favez, O., D'Anna, B., George, C., and Baltensperger, U.: Characterization of aerosol chemical composition with aerosol mass spectrometry in Central Europe: an overview, Atmos. Chem. Phys., 10, 10453-10471, doi:10.5194/acp-10-10453-2010, 2010.

Liu, Q., Sun, Y., Hu, B., Liu, Z., Akio, S., and Wang, Y.: In situ measurement of PM1 organic aerosol in Beijing winter using a high-resolution aerosol mass spectrometer, Chinese Sci. Bull., 57, 819-826, doi:10.1007/s11434-011-4886-0, 2012.

Meng, Z. Y., Lin, W. L., Jiang, X. M., Yan, P., Wang, Y., Zhang, Y. M., Jia, X. F., and Yu, X. L.: Characteristics of atmospheric ammonia over Beijing, China, Atmos. Chem. Phys., 11, 61396151, doi:10.5194/acp-11-6139-2011, 2011.

Middlebrook, A. M., Bahreini, R., Jimenez, J. L., and Canagaratna, M. R.: Evaluation of composition-dependent collection efficiencies for the Aerodyne Aerosol Mass Spectrometer using field data, Aerosol Sci. Tech., 46, 258-271, doi:10.1080/02786826.2011.620041, 2012.

Mohr, C., Richter, R., DeCarlo, P. F., Prévôt, A. S. H., and Baltensperger, U.: Spatial variation of chemical composition and sources of submicron aerosol in Zurich during wintertime using mobile aerosol mass spectrometer data, Atmos. Chem. Phys., 11, 7465-7482, doi:10.5194/acp-11-7465-2011, 2011.

Mohr, C., DeCarlo, P. F., Heringa, M. F., Chirico, R., Slowik, J. G., Richter, R., Reche, C., Alastuey, A., Querol, X., Seco, R., Peñuelas, J., Jiménez, J. L., Crippa, M., Zimmermann, R., Baltensperger, U., and Prévôt, A. S. H.: Identification and quantification of organic aerosol from cooking and other sources in Barcelona using aerosol mass spectrometer data, Atmos. Chem. Phys., 12, 1649-1665, doi:10.5194/acp-12-1649-2012, 2012.

Murphy, D. M., Cziczo, D. J., Froyd, K. D., Hudson, P. K., Matthew, B. M., Middlebrook, A. M., Peltier, R. E., Sullivan, A., Thomson, D. S., and Weber, R. J.: Single-particle mass spectrometry of tropospheric aerosol particles, J. Geophys. Res.-Atmos., 111, D23S32, doi:10.1029/2006jd007340, 2006.

Ng, N. L., Canagaratna, M. R., Zhang, Q., Jimenez, J. L., Tian, J., Ulbrich, I. M., Kroll, J. H., Docherty, K. S., Chhabra, P. S., Bahreini, R., Murphy, S. M., Seinfeld, J. H., Hildebrandt, L., Donahue, N. M., DeCarlo, P. F., Lanz, V. A., Prévôt, A. S. H., Dinar, E., Rudich, Y., and Worsnop, D. R.: Organic aerosol components observed in Northern Hemispheric datasets from Aerosol Mass Spectrometry, Atmos. Chem. Phys., 10, 46254641, doi:10.5194/acp-10-4625-2010, 2010.

Paatero, P. and Hopke, P. K.: Discarding or downweighting highnoise variables in factor analytic models, Anal. Chim. Acta, 490, 277-289, doi:10.1016/s0003-2670(02)01643-4, 2003.

Paatero, P. and Tapper, U.: Positive Matrix Factorization-a Nonnegative Factor Model with Optimal Utilization of Error-Estimates of Data Values, Environmetrics, 5, 111-126, 1994.

Ranjan, M., Presto, A. A., May, A. A., and Robinson, A. L.: Temperature Dependence of Gas-Particle Partitioning of Primary Organic Aerosol Emissions from a Small Diesel Engine, Aerosol Sci. Tech., 46, 13-21, 2012.

Setyan, A., Zhang, Q., Merkel, M., Knighton, W. B., Sun, Y., Song, C., Shilling, J. E., Onasch, T. B., Herndon, S. C., Worsnop, D. R., Fast, J. D., Zaveri, R. A., Berg, L. K., Wiedensohler, A., Flowers, B. A., Dubey, M. K., and Subramanian, R.: Characterization of submicron particles influenced by mixed biogenic and anthro- pogenic emissions using high-resolution aerosol mass spectrometry: results from CARES, Atmos. Chem. Phys., 12, 8131-8156, doi:10.5194/acp-12-8131-2012, 2012.

Shen, X., H., Lee, T. Y., Guo, J., Wang, X. F., Li, P. H., Xu, P. J., Wang, Y., Ren, Y., Wang, W., Wang, T., Cam, S. A., and Collett, J. L.: Aqueous phase sulfate production in clouds in eastern China, Atmos. Environ., 62, 502-511, doi:10.1016/j.atmosenv.2012.07.079, 2012.

Sun, J., Zhang, Q., Canagaratna, M. R., Zhang, Y., Ng, N. L., Sun, Y., Jayne, J. T., Zhang, X., Zhang, X., and Worsnop, D. R.: Highly time- and size-resolved characterization of submicron aerosol particles in Beijing using an Aerodyne Aerosol Mass Spectrometer, Atmos. Environ., 44, 131-140, doi:10.1016/j.atmosenv.2009.03.020, 2010.

Sun, Y. L., Zhang, Q., Macdonald, A. M., Hayden, K., Li, S. M., Liggio, J., Liu, P. S. K., Anlauf, K. G., Leaitch, W. R., Steffen, A., Cubison, M., Worsnop, D. R., van Donkelaar, A., and Martin, R. V.: Size-resolved aerosol chemistry on Whistler Mountain, Canada with a high-resolution aerosol mass spectrometer during INTEX-B, Atmos. Chem. Phys., 9, 3095-3111, doi:10.5194/acp9-3095-2009, 2009.

Sun, Y. L., Zhang, Q., Schwab, J. J., Chen, W. N., Bae, M. S., Lin, Y. C., Hung, H. M., and Demerjian, K. L.: A case study of aerosol processing and evolution in summer in New York City, Atmos. Chem. Phys., 11, 12737-12750, doi:10.5194/acp11-12737-2011, 2011a.

Sun, Y.-L., Zhang, Q., Schwab, J. J., Demerjian, K. L., Chen, W.N., Bae, M.-S., Hung, H.-M., Hogrefe, O., Frank, B., Rattigan, O. V., and Lin, Y.-C.: Characterization of the sources and processes of organic and inorganic aerosols in New York city with a high-resolution time-of-flight aerosol mass apectrometer, Atmos. Chem. Phys., 11, 1581-1602, doi:10.5194/acp-11-15812011, $2011 b$.

Sun, Y. L., Wang, Z. F., Dong, H. B., Yang, T., Li, J., Pan, X. L., Chen, P., and Jayne, J. T.: Characterization of summer organic and inorganic aerosols in Beijing, China with an Aerosol Chemical Speciation Monitor, Atmos. Environ., 51, 250-259, doi:10.1016/j.atmosenv.2012.01.013, 2012.

Sun, Y. L., Wang, Z. F., Fu, P. Q., Jiang, Q., Yang, T., Li, J., and Ge, X. L.: The impact of relative humidity on aerosol composition and evolution processes during wintertime in Beijing, China, Atmos. Environ., 77, 927-934, doi:10.1016/j.atmosenv.2013.06.019, 2013a.

Sun, Y. L., Wang, Z. F., Fu, P. Q., Yang, T., Jiang, Q., Dong, H. B., Li, J., and Jia, J. J.: Aerosol composition, sources and processes during wintertime in Beijing, China, Atmos. Chem. Phys., 13, 4577-4592, doi:10.5194/acp-13-4577-2013, 2013 b.

Turpin, B. J. and Lim, H.-J.: Species Contributions to $\mathrm{PM}_{2.5}$ Mass Concentrations: Revisiting Common Assumptions for Estimating Organic Mass, Aerosol. Sci. Tech., 35, 602-610, doi:10.1080/02786820119445, 2001.

Ulbrich, I. M., Canagaratna, M. R., Zhang, Q., Worsnop, D. R., and Jimenez, J. L.: Interpretation of organic components from Positive Matrix Factorization of aerosol mass spectrometric data, Atmos. Chem. Phys., 9, 2891-2918, doi:10.5194/acp-9-2891-2009, 2009.

Wang, X., Williams, B. J., Wang, X., Tang, Y., Huang, Y., Kong, L., Yang, X., and Biswas, P.: Characterization of organic aerosol produced during pulverized coal combustion in 
a drop tube furnace, Atmos. Chem. Phys., 13, 10919-10932, doi:10.5194/acp-13-10919-2013, 2013.

Xiao, R., Takegawa, N., Kondo, Y., Miyazaki, Y., Miyakawa, T., Hu, M., Shao, M., Zeng, L. M., Hofzumahaus, A., Holland, F., Lu, K., Sugimoto, N., Zhao, Y., and Zhang, Y. H.: Formation of submicron sulfate and organic aerosols in the outflow from the urban region of the Pearl River Delta in China, Atmos. Environ., 43, 3754-3763, doi:10.1016/j.atmosenv.2009.04.028, 2009.

Zhang, H., Wang, S., Hao, J., Wan, L., Jiang, J., Zhang, M., Mestl, H. E. S., Alnes, L. W. H., Aunan, K., and Mellouki, A. W.: Chemical and size characterization of particles emitted from the burning of coal and wood in rural households in Guizhou, China, Atmos. Environ., 51, 94-99, doi:10.1016/j.atmosenv.2012.01.042, 2012.

Zhang, Q., Canagaratna, M. R., Jayne, J. T., Worsnop, D. R., and Jimenez, J. L.: Time- and size resolved chemical composition of submicron particles in Pittsburgh: implications for aerosol sources and processes, J. Geophys. Res.-Atmos., 110, D07S09, doi:10.1029/2004jd004649, 2005a.

Zhang, Q., Worsnop, D. R., Canagaratna, M. R., and Jimenez, J. L.: Hydrocarbon-like and oxygenated organic aerosols in Pittsburgh: insights into sources and processes of organic aerosols, Atmos. Chem. Phys., 5, 3289-3311, doi:10.5194/acp-5-32892005, 2005b.
Zhang, Q., Jimenez, J. L., Canagaratna, M. R., Allan, J. D., Coe, H., Ulbrich, I., Alfarra, M. R., Takami, A., Middlebrook, A. M., Sun, Y. L., Dzepina, K., Dunlea, E., Docherty, K., DeCarlo, P. F., Salcedo, D., Onasch, T., Jayne, J. T., Miyoshi, T., Shimono, A., Hatakeyama, S., Takegawa, N., Kondo, Y., Schneider, J., Drewnick, F., Borrmann, S., Weimer, S., Demerjian, K., Williams, P., Bower, K., Bahreini, R., Cottrell, L., Griffin, R. J., Rautiainen, J., Sun, J. Y., Zhang, Y. M., and Worsnop, D. R.: Ubiquity and dominance of oxygenated species in organic aerosols in anthropogenically-influenced Northern Hemisphere midlatitudes, Geophys. Res. Lett., L13801, 34, doi:10.1029/2007g1029979, 2007.

Zhang, Y., Schauer, J. J., Zhang, Y., Zeng, L., Wei, Y., Liu, Y., and Shao, M.: Characteristics of Particulate Carbon Emissions from Real-World Chinese Coal Combustion, Environ. Sci. Technol., 42, 5068-5073, 2008. 